\title{
LONG-DISTANCE INFLUENCE OF THE RHÔNE RIVER PLUME ON THE MARINE BENTHIC ECOSYSTEM: INTEGRATING DESCRIPTIVE ECOLOGY AND PREDICTIVE MODELLING
}

Daniel Martin ${ }^{1}$, Francesco Pititto ${ }^{1}$, João Gil ${ }^{1,2}$, Maria Paola Mura ${ }^{1}$, Nixon Bahamon ${ }^{1,3}$, Chiara Romano ${ }^{1,4}$, Sébastien Thorin ${ }^{5}$, Thibault Shvartz ${ }^{5}$, Éric Dutrieux ${ }^{5}$ and Yannick Bocquenet $^{6}$

${ }^{1}$ Centre d'Estudis Avançats de Blanes (CEAB-CSIC). Carrer d'accés a la Cala Sant Francesc 14, 17300 Blanes, Girona, Catalunya, Spain

${ }^{2}$ Center of Marine Sciences, CCMAR, University of Algarve, Campus de Gambelas, 8005-139, Faro, Portugal

3 Institut de Ciències del Mar (ICM - CMIMA - CSIC). Passeig Marítim de la Barceloneta, 37-49. E-08003 Barcelona, Spain.

${ }^{4}$ Scripps Institution of Oceanography, 8750 Biological Grade, Hubbs Hall, La Jolla, CA 92037, USA

${ }^{5}$ Créocéan, 128 Avenue de Fes, 34080 Montpellier, France

${ }^{6}$ RTE (Réseau de Transport d'Electricité), France

* Corresponding author. Daniel Martin. E-mail: dani@ceab.csic.es 


\section{ABSTRACT}

The Gulf of Lions (GoL) is among the most productive areas of the Mediterranean Sea, with the Rhône River contributing with as much as $90 \%$ of the liquid and solid materials (including anthropogenic chemicals) reaching the area. In this paper, we assessed whether classical descriptive ecology and MaxEnt predictive species distribution modelling were able to provide complementary information when analysing the long-distance influence of the river discharges on the GoL benthic ecosystem. Samples were collected in August 2014 from 12 stations covering the sedimentary plain of the deep submarine delta, from the Gulf of Fos to Gruissan. Sediments were mostly muddy with a high organic carbon and low $\mathrm{P}$ and $\mathrm{N}$ contents first decreasing and then increasing from east to west. The same pattern occurred for chlorophyll-a, particulate organic carbon and sea surface temperature, and was overall correlated with metal and pollutant contents derived from agricultural, port, urban and industrial sources driven by Rhône outputs. We observed a typical deltaic succession in the benthos, showing a relatively low diversity and including polychaetes (Sternaspis scutata) and holothurians (Oestergrenia digitata) known to be indicators of high sedimentation rates. Overall, benthos showed an inversed pattern regarding environmental variables, an evident consequence of the Rhône River influence. The suitability of some species was either positively or negatively correlated with some of the environmental variables, producing species-specific predicted distribution patterns, with the highest amount of information allowing to predict distributions being mainly provided by organic pollutants. Even with a limited number of available samples, our integrated approach reveals to be a very robust tool to highlight hidden patterns and contributes to improve our knowledge on how river-mediated anthropogenic discharges may influence biodiversity distribution and functional patterns in marine benthic ecosystems.

\section{KEYWORDS}

Benthic ecosystem, river discharges, descriptive ecology, species distribution models, MaxEnt, Gulf of Lions, NW Mediterranean 


\section{INTRODUCTION}

The Gulf of Lions (GoL) is one of the most productive areas of the Mediterranean Sea (Durrieu de Madron et al., 2011) and the Rhône River contributes with about $90 \%$ of the liquid and solid (i.e., terrigenous) continental discharges reaching the GoL (Durrieu de Madron et al., 2000; Bourrin and Durrieu de Madron, 2006), partly supporting from $23 \%$ to $69 \%$ of the existing primary production (Ludwig et al., 2009). Together with nutrients, terrigenous particles and fresh water, many chemicals of anthropogenic origin also reach the GoL, mainly as river discharges (Lorthiois et al., 2012; Fraysse et al., 2014) or flood events (Ollivier et al., 2011; Oursel et al., 2014).

In accordance with the Rhône River dimensions and flow regime, the associated plume extends far beyond the coastal areas and shows striking dimensions (Lorthiois et al., 2012). The plume biogeochemical characteristics and dynamics in the vicinity of the river mouth has been extensively investigated, based on both observations and numerical modelling (Fraysse et al., 2014). Physical processes driving the GoL oceanographic regime are highly variable. Among them, the most important are dense water formation and cascading, upwelling cells, continental winds, storms, and largescale circulation induced by the Northern Current along the continental slope (Millot, 1990; Millot, 1999). However, they are usually combined with the Coriolis acceleration to give rise to an overall preferential plume direction, typically deflecting westward in a clockwise orientation (Fraysse et al., 2014) and usually running from east to west. It is also well know that, in these circumstances, the plume may cross the GoL to reach the Camargue French coasts (Estournel et al., 1997) and was even detected west to Cape of Creus (Castellón et al., 1984), likely combined with those from other rivers flowing into the GoL, such as the Tet. As a result, the terrigenous materials carried by the Rhône 
plume are deposited at progressively longer distances along the prodelta, with the corresponding sedimentation rates decreasing from 0.40 to $0.65 \mathrm{~cm} \cdot \mathrm{y}^{-1}$ (Radakovitch et al., 1999; Miralles et al., 2005). Thus, the Rhône prodelta functions as a transitional depositional area for riverine transported materials and contaminants (Roussiez et al., 2005a; Roussiez et al., 2005b; Ollivier et al., 2011; Dumas et al., 2015), which may be easily resuspended offshore and towards deeper bottoms, mostly during storm events (Ulses et al., 2008; Dufois et al., 2014).

Since Rhoads et al. (1985) proposed their classical conceptual model, the longterm impact of riverine inputs in controlling benthic macrofauna composition and structure has been well-recognized. The combination of the GoL oceanographic regime drivers with the dynamics and characteristics of the Rhône River outputs and its associated plume thus provides an excellent scenario to assess the long-distance influence of the river on the benthic compartment, both in terms of sediment patterns and its associated macroinfauna. The characteristics of the bottom surface sediments off the Rhône River mouth have been reported either by addressing the temporal variability of the remineralization processes of a limited set of sediment variables and the spatial variability of a larger set of variables, or by using both temporal and spatial variability, based on observational data and numerical modelling (Bonifácio et al., 2014; Dufois et al., 2014). Benthic macrofauna composition showed marked longitudinal gradients originated at the Rhône River mouth, which were highly dependent on the temporal changes in riverine water flow (Salen-Picard and Arlhac, 2002; Salen-Picard et al., 2003; Hermand et al., 2008; Harmelin-Vivien et al., 2009; Labrune et al., 2012; Bonifácio et al., 2014). However, all these studies covered areas nearby the GoL east coast, with the farthest station being less than $15 \mathrm{~km}$ westward the river mouth. 
Numerical models are a basic tool to fill the gap between the understanding of sediment-transport processes based on local observations and sedimentation patterns over larger areas (Syvitski and Bahr, 2001). Also, they are commonly used in oceanography to interpolate between sparse ocean observations (e.g., produced by ships, drifters, satellites) to provide accurate simulations in realistic ocean basins and sea floors (Stewart, 2006). Coupling physical numerical models with biogeochemical and population models (mostly from fish and plankton), is also a rapidly growing field (Fennel and Neumann, 2015).

Even though benthic organisms are widely recognized as bioindicators (Borja et al., 2000), the application of ecological modelling on marine benthos is so far limited (except for organisms with planktonic dispersal larvae, e.g., Guizien et al. (2014)), this being an evident gap in the joint use of physical and biological models in marine environments. Nevertheless, the availability of maps plotting the actual and potential benthic species distribution seems an essential tool for conservation biology, as well as for seafloor habitats' monitoring and management. Spatial statistics and species distribution models (SDMs) have been recently used to investigate the distribution of species over large areas all around the world (Franklin, 2009) in conjunction with Geographical Information Systems (GIS), while predictive modelling has revealed to be useful in understanding the relationships between time-dependent processes and spatialrelated distributions (Holmes et al., 2008).

Among SDMs, Maximum Entropy (MaxEnt) shows high performance in modelling the distribution of "presence-only" species data occurrence (Elith et al., 2006; Phillips et al., 2006; Pearson et al., 2007; Phillips and Dudík, 2008; Elith et al., 2011), in particular for small samples (Pearson et al., 2007; Yackulic et al., 2013) where model complexity and spatial bias may reduce the quality of the obtained distributions 
(Phillips and Dudík, 2008; Warren and Seifert, 2011; Beck et al., 2014). MaxEnt may predict the species environmental suitability by analysing the constraints between presence-only data and environmental variables (Phillips and Dudík, 2008; Crafton, 2015). Then, it may provide the likelihood ratio of an average presence to an average background point by maximising a penalized maximum likelihood function (so-called gain function). This way, MaxEnt provides a model that best differentiates presence from background locations (Merow et al., 2013). Accordingly, this tool allows forecasting changes in benthic organisms' distribution, drawing up maps based on predicting the presence of target species in non-sampled areas with comparable environmental conditions (Elith et al., 2011; Bradie and Leung, 2017; Breiner et al., 2017; Phillips, 2017), which availability is a priority for environmental planning and management (Vassallo et al., 2018). Therefore, MaxEnt emerges as a powerful tool to foster better decision-making processes (e.g. within the objectives of the European Marine Strategy Framework Directive) (Lynam et al., 2016), and proved to be useful in several aspects of biological interest: (a) for conservation and management of threatened species, in particular within the IUCN Red List framework (Syfert et al., 2014; Miller et al., 2015; Breiner et al., 2017); (b) for invasive species management (Azzurro et al., 2013; Guillera-Arroita et al., 2015), (c) for predicting the potential impacts of climate changes on species distribution range size (Guillera-Arroita et al., 2015); and (d) for ecological and biogeographical inference (Reiss et al., 2011; González-Irusta et al., 2015).

In this context, we expected both classical descriptive ecology and MaxEnt predictive species distribution modelling approaches to be able to provide complementary information based on the same dataset, the former highlighting the main dominant trends, the latter pointing on species distributions and highlighting the most 
explanatory environmental variables. Therefore, we used (1) the composition of the bottom surface sediments (viz. granulometry, metal content, pollutants) and (2) the structure of the benthic macroinfauna, to compare the performances of both approaches in assessing the long-distance influence of the Rhône River water outputs (including anthropogenic pollutants) flowing into the GoL.

\section{MATERIAL AND METHODS}

\subsection{Sample collection and tratments}

Thirty-six samples were collected in August 2014 from 12 stations located at $15 \mathrm{~km}$ intervals (except S10 to S11 and S11 to S12 that are at $4 \mathrm{~km}$ intervals) along a transect crossing the GoL, from off Gruissan to the eastern side of the Gulf of Fos (French coast, NW Mediterranean) (Fig. 1).

At each station, one-litre of sediment from a van Veen grab $(35 \times 42 \times 90 \mathrm{~cm}$, about $0.1 \mathrm{~m}^{2}$ sampling area) was collected for physico-chemical analyses (viz. granulometry, water content, organic matter, organic carbon), transferred into a widemouthed double-closing $500 \mathrm{~mL}$ polyethylene flasks, stored in the dark and transferred to the laboratory. All sediment physico-chemical analyses (Table 1) were performed by CARSO - Laboratoire Santé Environnement Hygiène de Lyon, a laboratory for water analysis authorized by the French Ministry of Health (Accreditation $\mathrm{N}^{\circ} 1-1531$, NF EN ISO/CEI 17025: 2005 by COFRAC, www.cofrac.fr). Sediments were classified according to the following granulometric classes: clay $(<2 \mu \mathrm{m})$, silt $(2-63 \mu \mathrm{m})$, very fine sands $(64-160 \mu \mathrm{m})$, fine sands $(160-250 \mu \mathrm{m})$, medium sands $(250-500 \mu \mathrm{m})$, and coarse sands (> $500 \mu \mathrm{m}$ ) after sifting through a $2 \mathrm{~mm}$ mesh sieve. Metal and organic pollutant contents were checked against the $\mathrm{N} 1$ thresholds defined by the 
OSPAR Commission (the level below which dredging and relocation activities would be authorised without further control), the known background levels and the ecotoxicological criteria (Alzieu et al., 1999; Webster et al., 2009; Bataille et al., 2010; Larsen and Fryer, 2015) (Table 2). Polycyclic Aromatic Hydrocarbons (PAHs) were represented by the sum of all individual compounds analysed (i.e., acenaphthylene, fluoranthene, Benzo (b) fluoranthene, Benzo (k) fluoranthene, Benzo (a) pyrene, Benzo (ghi) perylene, Indeno (1,2,3 cd) pyrene, anthracene, acenaphthene, chrysene, Dibenzo (a, h) anthracene, fluorene, naphthalene, pyrene, phenanthrene, Benzo (a) anthracene). Polychlorinated biphenyls (PCBs) were represented by the sum of all individual congeneric PCBs $(28,52,101,118,138,153,180)$. Organotins were represented by Monobutyltin, Dibutyl, Tributyltin and Triphenyltin (g/Kg DW). Total tin and all emerging pollutans (Tables 3 and S1) were analysed on selected stations along the transects to avoid overscoping, as many of them were expected to be under detection levels according to preliminary surveys (ST, TS and ED, unpublished data).

Sea surface satellite-derived chlorophylls (chl-a), particulate organic carbon (POC) and seawater surface temperature (TEMP) were processed as potential tracers of the plume of the river Rhône impacting the GoL seafloor (Lorthiois et al., 2012). We used Level $3(4 \times 4 \mathrm{~km}$ resolution) MODIS-Aqua products for the stations along the transect, extracted from NASA databases (http://oceancolor.gsfc.nasa.gov/). Assuming life-spans no longer than 1-2 years for most infaunal benthic organisms, 8-day composite images collected since January 1, 2013 to August 12, 2014 were averaged over $36 \mathrm{~km}^{2}$ (9 pixels) around each one of the stations along the transect. The spatial resolution and composition of images in time guaranteed the absence of clouds and allowed full access to all the required information from all stations. Following Bernardello et al. (2016), we considered that the selected space resolution of the images 
was representative enough for the stations, providing validated estimations for even near-shore areas. However, due to the reduced area covered nearshore, the images closer to the River Rhône mouth overlapped partially. Salinity could have been also a good indicator of the river dispersion pattern (even better than TEMP), but satellite data (from SMOS and AQUARIOUS) were not available for near shore areas.

At each station, three replicate samples were collected to analyze the macroinfauna with the same van Veen grab as for sediment analyses. Grab contents were gently mixed in a container, then sieved out on board by pouring them through a 1 $\mathrm{mm}$ mesh sieve. The retained sediments were transferred to a plastic bag, fixed with a 4\% formaldehyde/seawater solution, stained with Rose Bengal and stored until sorting. Macroinfaunal invertebrates were initially sorted under a stereomicroscope, grouped in major taxa, and stored in $70 \%$ ethanol. All organisms were then identified to the lowest taxonomic level possible, counted and preserved in $70 \%$ ethanol. Macrofaunal densities were expressed as number of individuals per square meter $\left(\mathrm{ind} / \mathrm{m}^{2}\right)$. Biomasses were estimated as dry weight $\left(24 \mathrm{~h}, 100^{\circ} \mathrm{C}\right)$ and expressed as mg per square meter $\left(\mathrm{mg} / \mathrm{m}^{2}\right)$.

All organisms identified in this study are deposited at the collections of the CEAB-CSIC, where they are available for public consultancy. Both the environmental and assemblage datasets are publicly available at the institutional repository of the CSIC at http://dx.doi.org/10.20350/digitalCSIC/8626.

\subsection{Data analyses}

Species richness, Shannon diversity (Shannon, 1948) and Pielou's (Pielou, 1969) were estimated using the DIVERSE routine of the PRIMER 6 and PERMANOVA versions 6.1.11 and 1.0.1 (C) PRIMER-e 2008) (Clarke and Gorley, 2006). The following trophic and biotic indexes were also estimated: trophic index (TI) (Word, 1990), AZTI Marine 
Biotic Index (AMBI) (Borja et al., 2000) and multivariate AMBI (m-AMBI) (Bald et al., 2005; Muxika et al., 2007). A TI 60\% threshold defines the boundary between dynamic environments (TI $>60 \%$ ), where the organic material is quickly integrated into the food chain, and the environments where organic matter tends to accumulate due to slow degradation ( $\mathrm{TI}<60 \%$ ), causing excessive enrichment and disturbing sediment (Word, 1990).

The relationships between environmental variables, including the distance from the Rhône River mouth (namely "the distance") and assemblage descriptors were assessed by correspondence analyses (Pearson Index) using the XLSTAT version 2015.4.01.20382 (C) Addinsoft 1995-2015) routines for Office 2010 Excel version 14.0.7153.5000 (C) Microsoft Corporation 2010).

The relationships between sampling stations based on the environmental variables and assemblage descriptors were assessed by a non-parametric multidimensional scaling (MDS) and the species determining the similarities within and the differences between the identified groups were assessed by the SIMPER analysis using the respective PRIMER 6 routines. The significance of the differences in environmental variables and assemblage descriptors between the groups obtained in the MDS were assessed by oneway ANOVA. The responsible of the significant effects were assessed by Tukey Honest Significant Difference test (Tukey HSD) and, alternatively when this test was not resolutive enough, by the Student Newman-Keuls test (SNK). These analyses were performed by means of the XLSTAT routines for Excel. When required, data were logtransformed and/or normalised to meet the assumptions of normality and homoscedasticity (Zar, 1984), as tested by Kolmogorov-Smirnov and Bartlett test, respectively. 
Species' distribution modelling was carried out using the MaxEnt software version 3.4.1 (Phillips et al., 2017). MaxEnt is based on presence-only species occurrence and predicts the species suitability based on the constraints between occurrence data and environmental variables (Phillips et al., 2006; Elith et al., 2011; Merow et al., 2013; Phillips et al., 2017). All available variables (Table 1) were used as model environmental layer and the MaxEnt's machine learning algorithm highlighted the most relevant allowing to predict the species distributions through a regularization process (Elith et al., 2006; Phillips et al., 2006; Merow et al., 2013). The presence data of the species identified during our study, together with those available from Créocéan Gulf of Fos and Gruissan, same year and identification standards (ST, TS and ED, unpublished data) - were used as model inputs to improve the predicted distributions.

Preliminary analyses allowed us to select the following species as examples to run the MaxEnt predictive modelling: the polychaetes Sternaspis scutata (Ranzani, 1817), Aponuphis ornata (Fauvel, 1928), Drilonereis filum (Claparède, 1868), Lumbrineris latreilli Audouin and Milne Edwards, 1833, Goniada maculata Örsted, 1843, Levinsenia sp.1, Glycera unicornis Savigny in Lamarck, 1818, Mastobranchus trinchesii Eisig, 1887 and Nephtys kersivalensis McIntosh, 1908, the echinoderms Oestergrenia digitata (Montagu, 1816) and Amphiura chiajei Forbes, 1843, and the bivalve molluscs Nucula sulcata Bronn, 1831 and Thyasira flexuosa (Montagu, 1803). Then, we ran MaxEnt several times, fine tuning the default configuration of the model's parameters as follows:

- Regularization multipliers: for each species, we selected the configuration showing the best fitting omission rate and the highest area under curve (AUC) scores (Elith et al., 2006; Phillips and Dudík, 2008; Anderson and Gonzalez, 
2011; Merow et al., 2013; Shcheglovitova and Anderson, 2013; Radosavljevic et al., 2014; Phillips et al., 2017);

- Average distribution: obtained by bootstrap for each species (Elith et al., 2006; Phillips et al., 2006; Pearson et al., 2007; Merow et al., 2013; Phillips, 2017);

- Convergence threshold: set to 0.001 ;

- Maximum number of iterations: set to 2,500;

- Most relevant variables: identified by Jack-knife test for each species distribution (Phillips et al., 2006; Phillips, 2017);

- Feature types: linear and quadratic, as suggested in case of having a limited number of samples (Pearson et al., 2007; Wisz et al., 2008; Merow et al., 2013; Shcheglovitova and Anderson, 2013);

- Threshold rule: set to minimum training presence;

- Selected output format: set to clogs-log as an estimate of presence probabilities (Phillips, 2017).

The model runs were carried out at the computational biology laboratory of the CEAB-CSIC using a cluster of 30 CPUs with $10 \mathrm{~Gb}$ ram each. For each examined species, the prediction map was also drawn up and imported in the ESRI ArcGIS 10.6 program for further elaborations and considerations.

\section{RESULTS}

\subsection{Environmental variables}

\subsubsection{Sediments}

Except in two shallow water stations (S1 and S12), the sediments along the study transect (Fig. 2) were composed by more than $90 \%$ of clay and silt, independently from 
the distance. Clay showed a maximum at S5 (ca. 18\%) and progressively decreased toward S1 and S12 to less than $10 \%$, while the remaining sediment fractions were usually lower than 5\% and tended to show relative maximums at $\mathrm{S} 1$ and $\mathrm{S} 12$, but also at S5. Except at S1 and S2, OM was slightly lower than 60\%, while PW showed an inverse pattern, with all values higher than $40 \%$ except at S1, S2, S5 and S11. Maximal OC were recorded at S8, S9 and S12, being lower than 16\% in the remaining sites (Fig. 2). Decreases in N occurred from the river mouth towards both S1 and S12 (although there was a slight peak at S3 and S4). In the case of $\mathrm{P}$, the overall trend resembled that of $\mathrm{N}$, but the minimum occurred at S3 (Fig. 2).

No significant correlations occurred between the granulometry, the distance and depth, although fine sand tended to decrease slightly with the increasing depth. Although non-significant, $\mathrm{OM}$ also tended to decrease with the increasing depth, while PW tended to increase. Significant, negative correlations occurred between OC and clay (Pearson correlation $=-0.721, p=0.008$ ), and between $\mathrm{N}$ and the distance (Pearson correlation $=-0.769, p=0.003)$ while $\mathrm{P}$ did not show any significant correlation with the other environmental variables.

\subsubsection{Sediment trace metal contents}

All sampled stations showed metal contents lower than their N1 thresholds, being of the same magnitude (or even lower) than the background levels. Except for Ar, Al and $\mathrm{Cd}$, the contents of all metals decreased more or less progressively towards $\mathrm{S} 1$, and were markedly fluctuant towards S12 (Fig. 3). There were about $10 \mathrm{mg} / \mathrm{Kg}$ in dry weight (DW) of $\mathrm{Ar}$ and $10-15 \mathrm{mg} / \mathrm{Kg} \mathrm{DW}$ of $\mathrm{Al}$ along the whole transect, except at S4 $(>15 \mathrm{mg} / \mathrm{Kg} \mathrm{DW})$ and $\mathrm{S} 9(>25 \mathrm{mg} / \mathrm{Kg} \mathrm{DW})$, respectively. The most peculiar trend was 
observed for Cd, which showed concentrations of ca. $0.2 \mathrm{mg} / \mathrm{Kg}$ DW from $\mathrm{S} 8$ to $\mathrm{S} 11$ and of ca. $0.1 \mathrm{mg} / \mathrm{Kg} \mathrm{DW}$ in all remaining stations.

All metals were negatively correlated with the distance (Pearson correlation ranging from -0.617 to $-0.830, p<0.05)$ except Ar and Al. The former was positively correlated with depth (Pearson correlation $=0.635, p=0.026$ ), while the latter neither correlated with the distance nor with depth. The contents of Ni and Fe decreased with the increasing fine sands, but the correlation was only significant in the case of $\mathrm{Ni}$ (Pearson correlation $=-0.598, p=0.040)$ and, although not statistically significant, both tended to increase with the increasing silt and clay. In turn, Ni significantly increased with the increasing PW and decreased with the increasing OM (Pearson correlation = 0.693 and -0.693 , respectively, $p=0.012$ ).

\subsubsection{Sediment content in organic and microbial pollutants}

The concentrations of PAHs, HYDs and PCBs were always lower than the corresponding N1 threshold along all stations. However, they were slightly higher towards S12, particularly at S10 (HYDs) and S11 (PAHs and PCBs) (Fig. 4), showing a maximum near the river mouth, and significantly decreasing with the increasing distance (Pearson correlation $=-0.669,-0.724$ and $-0.683, p=0.017,0.008$ and 0.014 , respectively). Organotin compounds (monobutyltins, dibutyltins, tributyltins and triphenyltins) were always under the level of detection. Among the emerging pollutants, only six overpassed the levels of detection, showing overall trends to slightly decrease with the increasing distance, except the total amount of octa-BDE, which was almost constant except for a peak at S5 (Tables 3 and S1). Escherichia coli and enterococci were also always under the levels of detection, except at $\mathrm{S} 1$ and $\mathrm{S} 6\left(58 \mathrm{E}\right.$. coli $\left.\cdot \mathrm{g}^{-1}\right)$ and 
S7 (119 enterococci $\left.\cdot \mathrm{g}^{-1}\right)$. Indeed, these values were very low, thus supporting an overall absence of significant microbial contamination.

\subsubsection{Water surface variables}

On average, chl-a, POC and TEMP were $1.22 \pm 0.48 \mathrm{mg} / \mathrm{m}^{3}, 209.19 \pm 47.85 \mathrm{mg} / \mathrm{m}^{3}$ and $16.46 \pm 0.31{ }^{\circ} \mathrm{C}$, respectively (Fig. 4). The patterns of chl-a and POC were significantly similar (Pearson correlation $=0.740, p=0.006$ ), showing pronounced intra-station variability, with maxima at S8, a progressive decrease towards S3 and a slight increase at S1 and S2. There was also a significant increase of benthic OC together with the increasing POC (Pearson correlation $=0.611, p=0.035)$. In turn, TEMP decreased progressively towards S1, as highlighted by the significant negative correlation with the distance (Pearson correlation $=-0.904, p<0.0001)$. TEMP showed also positive correlations with all environmental variables tending to decrease towards S1, including most metals (e.g., Cd, Cr, $\mathrm{Cu}, \mathrm{Hg}, \mathrm{Ni}$, and $\mathrm{Zn}$, Pearson correlation from 0.579 to 0.784 , $p<0.05$ ) and HYDs, PAHs and PCBs (Pearson correlations $=0.756,0.740$ and $0.780, p$ $=0.004,0.006$ and 0.003$)$.

\subsection{Assemblage descriptors}

We counted and identified 428 specimens of infaunal benthic invertebrates, which were dominated by polychaetes in terms of abundance (57\%) while only representing $9.4 \%$ of the total biomass. Among them, the most abundant species was the sternaspid Sternaspis scutata $(11.7 \%$ of abundance, but $0.3 \%$ of biomass), while the most representative in terms of biomass were the onuphid Aponuphis ornata and the oenonid Drilonereis filum (15\% of biomass, but $2.8 \%$ and $0.9 \%$ of abundance, respectively). Echinoderms dominated in terms of biomass (78.3\%), particularly the phyllophorid 
holothurian Thione cf. inermis (69.3\%), which contributed to an $11.4 \%$ and $7.7 \%$ of the abundance, respectively. Crustaceans, (mainly amphipods) represented $14 \%$ in abundance and $7.9 \%$ in biomass, while molluscs (mainly bivalves) represented $10.7 \%$ and $2.6 \%$, respectively.

The average density was $119 \pm 109 \mathrm{ind} / \mathrm{m}^{2}$, the average biomass $1.01 \pm 0.89 \mathrm{~g} / \mathrm{m}^{2}$, the average richness $17.08 \pm 14.52$ species per station, the average diversity $3.38 \pm 0.84$ bits, and the average evenness $89.95 \pm 5.36 \%$ (Fig. 5). None of them showed significant correlations with distance and depth. Except for evenness, all descriptors clearly increased from the river mouth towards S1 and S12, with S8 and S11 (density), S2 and S8 (biomass), and S11 (richness and diversity) disturbing the main trend (Fig. 5). In turn, evenness was minimal (i.e. $<85 \%$ ) at $\mathrm{S} 1, \mathrm{~S} 2$ and $\mathrm{S} 8$, highly variable from $\mathrm{S} 9$ to S12, and higher than $90 \%$ from S3 to S7.

On average TI, AMBI and M-AMBI were 56.19 $\pm 8.94 \%, 1.76 \pm 0.25$ and $0.48 \pm$ 0.06, respectively (Fig. 5). Again, there were no significant correlations between them and the distance and depth. Minimum TI (around 40\%) occurred at S5 and S9, and maxima (slightly overpassing 60\%) at S2, S8 and S12. Along the studied transect, TI bordered the $60 \%$ threshold, indicating a tendency towards disturbance and excessive organic enrichment that may certainly be related with the plume influence. Despite the high intra-station variability, the average AMBI per station was almost constant, with relative minima at $\mathrm{S} 3$ and $\mathrm{S} 10$, and ranged always from good to very good scores. The M-AMBI was less good (i.e., ranging from average to mediocre), with a slight increase in quality when moving far from the river mouth. As for the relationships between assemblage descriptors and environmental variables, there were positive correlations between density and OM, biomass and very fine sands and OM, evenness and PW, TI and $\mathrm{OC}$, and $\mathrm{AMBI}$ and $\mathrm{Pb}$. Negative correlations occurred between density and $\mathrm{PW}$ 
and $\mathrm{Ni}$, biomass and silt and PW, evenness and $\mathrm{OM}$ and $\mathrm{Fe}$, Ti and silt and $\mathrm{Ni}$, and $\mathrm{M}-$ AMBI and Fe and Ni (Table 4). In turn, there were no significant relationships between assemblage descriptors and water surface variables.

\subsection{Structure of the assemblages}

The MDS based on environmental variables (Fig. 6A) revealed a clear structure in stations' organisation, with a focus point at the river mouth. Accordingly, four groups were identified: Close1 (S8-S10) and Close2 (S11), including stations nearby the river mouth; Intermediate (S3-S7), including stations at intermediary distances; and Far (S1, S2, S12), including stations from the two extremes of the transect. There were significant differences among them (ANOSIM: Global $\mathrm{R}=0.653$, Significance Level $<$ 0.001) and the responsible were the differences between Far and Closel vs. Intermediate (Pairwise tests, $\mathrm{R}$ Statistic $=0.610$ and 0.672 , Significance level $=0.018$ and 0.036 , respectively). The groups were even more clearly identifiable and significant when including both environmental variables and assemblage descriptors (Fig. 6B, ANOSIM: Global $\mathrm{R}=0.783$, Significance Level $<0.001)$ and the responsible were again Far and Close1 vs. Intermediate (Pairwise tests, R Statistic $=0.795$ and 0.692 , Significance level $=0.018$ and 0.036 , respectively). Conversely, in the MDS based on the species per sample matrix (Fig. 6C) Far and Close2 were clearly identifiable, while Close1 and Intermediate were almost overlapping, although the overall differences were significant (ANOSIM, Global $\mathrm{R}=0.071$, Significance Level $<0.001$ ) and the responsible were Close1 and Close2 vs. Far (Pairwise tests, R Statistic $=0.319$ and 0.662 , Significance level $=0.001$ and 0.005 , respectively). In all cases, the within-group similarities were lower than $25 \%$, with the lowest at Intermediate, and the most contributing species were mainly polychaetes (Table 5). The between-group 
dissimilarities were always higher that $85 \%$, with the highest (i.e., $>90 \%$ ) always involving Close2, and the most contributing species were also polychaetes, as well as a holothurian (Table 6).

Some environmental variables significantly differed among the MDS groups (Table 7, Fig. 7). Far showed significantly lower clay (Tukey HSD =3.202, $p=0.003$ ), silt $(\mathrm{SNK}>3, p<0.03)$ and PW (Tukey HSD $=3.202, p<0.03)$, and significantly higher very fine sand (Tukey HSD = 3.2, $p<0.03$ ), OM (Tukey HSD = 3.202, $p<0.03$ ) and $\mathrm{Ni}$ (Tukey $\mathrm{HSD}=3.202, p<0.03$ ). Among metals, only $\mathrm{Cr}, \mathrm{Cu}, \mathrm{Hg}$ and $\mathrm{Cd}$ differed significantly (Table 7, Fig. 8), being overall lower in Far and Intermediate than in Close1 and Close2 $(\mathrm{SNK}=2.858, p=0.035$; Tukey HSD $=3.202, p<0.03$; Tukey HSD $=3.202, p<0.0001$; and Tukey HSD $=3.202, p<0.001$, respectively). Among organic pollutants, PAHs and PCBs differed significantly (Table 7, Fig. 8), with the significantly higher contents at Close2 being the main responsible (PAHs: Tukey HSD $=3.202, p<0.016$; PCBs: Tukey HSD $=3.202, p<0.001$ ), but also Closel in the case of PCBs (Tukey HSD $=3.200, p=0.030$ and 0.037 , respectively).

Species Richness, density, diversity and biomass significantly differed among the MDS groups (Table 7, Fig. 9), with the first three descriptors being significantly higher at Close2 (Tukey HSD $=3.202, p<0.003,0.036$ and 0.02 , respectively) and biomass being significantly higher at Far (Tukey HSD $=3.202, p<0.01$ ). In the case of evenness, TI, AMBI, and M-AMBI, there were non-significant differences between the MDS groups (Table 7), although the evenness tended to be lower at Far and Close1 than at Intermediate and Close2, TI tended to be higher at Far, and M-AMBI tended to be higher at Close2 (Fig. 9).

\subsection{Species distribution model}


The best tuning of the models resulted from combining linear and quadratic features, with regularization multipliers equal to 5 for D. filum, M. trinchesii, N. kersivalensis and T. flexuosa and to 4 for all other (Table 8). The variables most influencing the suitability (negatively or positively) were basically related with granulometry, although chl-a, anthracene, and PCBs were also relevant for some species (Table 8).

Qualitatively, the following three main patterns emerged from the species distribution modelling:

- Sternaspis scutata is more likely to be present in the shallow eastern region of the study area, in the central region and in a spot in the west (Fig. 10A);

- Driloneris filum has a spot of suitability on the central region of the study area (Fig.10B), as well as L. latreilli, G. maculata, Levinsenia sp.1, O. digitata and A. chiajei;

- Glycera unicornis, N. sulcata, T. flexuosa and are more likely distributed in the eastern region (Fig 10C-E).

The most effective single variables predicting distributions were: Indeno(1,2,3cd)pyrene and Dibenz(a,h)anthracene for S. scutata, N. sulcata and T. flexuosa; Indeno(1,2,3-cd)pyrene for G. unicornis; Cd for D. filum; and Dibenz(a,h)anthracene for all remaining species (Fig. 11, S1, S2, S3, S4).

For all species, Indeno(1,2,3-cd)pyrene contains enough information not included in other variables so that omitting it considerably decreased the total gain of the model (Phillips, 2017). Other variables providing enough unique information were:

- Dibenz(a,h)anthracene for S. scutata, L. latreilli, G. unicornis and O. digitata;

- PCB52 for A. ornata, D. filum, M. trinchesii, N. kersivalensis and T. flexuosa; - Cd for D. filum. 


\section{DISCUSSION}

\subsection{Environmental framework}

The sediment characteristics along the transect agreed with the main trends explaining transport and erosive processes in the GoL, in which circulation combines with flooding events and extreme storms in defining the sedimentation pattern (Ulses et al., 2008; Dufois et al., 2014). The observed peculiarities in the eastern and a central (below $50 \mathrm{~m}$ depth) regions of the GoL can be explained by a lowered resuspension due to a relatively low wave and near bottom current influence (Ulses et al., 2008). In turn, the slight increase in coarser sediments in the proximal prodelta (facing the river mouth) could be attributed to a relatively higher sedimentation of fine sands (Labrune et al., 2012). The observed patterns of N, P and OC also responds to a progressively decreasing river influence. Near the mouth, the relationships between $\mathrm{OC}$ and granulometry appear to be positive (Labrune et al., 2012; Bonifácio et al., 2014), while we demonstrate negative relationships with silt and clay (i.e., those being most affected by resuspension) along our transect, which could be explained by the influence of major oceanographic drivers (e.g., waves and currents). In turn, we must take into account that the punctual character of our study did not allow us to discard the existence of temporal patterns (e.g., linked to seasonality or flooding events). However, the persistence of the observed patterns is supported by the fact that the remote sensing variables (which, to some extent, integrate time) also showed overall westward lowering trends and major river influences from $50 \mathrm{~km}$ off the mouth to up to $100 \mathrm{~km}$ away.

Most dissolved elements reaching the NW Mediterranean come from atmospheric inputs, while the Rhône outputs are the main source of particulate elements (Ollivier et 
al., 2011; Salvadó et al., 2013), and its prodelta works as an effective sink for riverine particle-reactive elements and chemical pollutants (Radakovitch et al., 1999). The origin of sunk metals could either be mostly industrial (e.g., $\mathrm{Cd}$ and $\mathrm{Pb}$ ) or agricultural (e.g., $\mathrm{Cu}$ ), the former being mainly associated to the Rhône River and the latter to the Tet River that flows into the GoL western coast (Roussiez et al., 2005b; Dumas et al., 2015). However, the placement of our stations and the habitual GoL circulation discarded the Tet influence, so that the observed overall westward decrease in metal contents (particularly for $\mathrm{Cr}, \mathrm{Cu}, \mathrm{Hg}, \mathrm{Ni}, \mathrm{Pb}$ and $\mathrm{Zn}$ ) could be better attributed to a fading Rhône influence. In spite of this, all trace metals we have analysed were close to background levels and never surpassed the OSPAR ecotoxicity criteria, with only Ni (over all the transect) and $\mathrm{Hg}$ (at S11) approaching the reference level. Therefore, the studied area can be considered as little or no contaminated by metals. Westward decreasing gradients also occurred for HYDs, PAHs and PCBs, which only overpassed the OSPAR N1 threshold towards the east of the river mouth. This was probably the most confined area, affected by the highly contaminated Gulf of Fos waters (e.g., Siron et al., 1987) that suffer from the influence of numerous harbour facilities and heavy industries (Larsen and Fryer, 2015). However, organotin (a tracer of antifouling paintings) was always below detection level, while those emerging pollutants overpassing it (i.e. pesticides, dioxins, polybrominated diphenyl ethers and tin) showed also an overall westward decrease and similar or slightly higher contents than previously reported (Salvadó et al., 2013). However, there are no quality standards or ecotoxicity thresholds established under national or international regulations. The only exceptions are probably those from the NOAA's Sediment Quality Guidelines referring to DDTs (de Mora et al., 2004) and PCBs (Long et al., 1995), which were clearly exceeded in the GoL, in agreement with previous studies (Salvadó et al., 2013). The influence of these pollutants is often 
difficult to distinguish at the assemblage level, likely being only significant for highly sensitive species. However, polychaetes are known to bioaccumulate organic pollutants and metals (Casado-Martinez et al., 2008) which, by triggering failed recruitment and poor juvenile survival, may cause significant impacts over multiple years (Blanchard et al., 2011). Thus, although not evidenced by our classical ecological approach, the influence of pollutants on the macrofaunal assemblage patterns cannot be fully discarded

\subsection{Structure of the macrobenthic assemblages}

The shallow GoL benthic assemblages directly under the influence of the Rhône discharges showed a typical deltaic succession modulated by regular terrestrial OM runoffs, only altered by episodic flooding (Hermand et al., 2008). Close to the river mouth, they mostly corresponded to the biocoenosis associated to muddy bottoms rich in silt and clay, i.e., the so called "Vases Terrigènes Côtières" (Terrigenous Coastal Muds) described by Pérès and Picard (1964) (see Bonifácio et al., 2014 and references therein). Some characteristic species - such as the polychaete $S$. scutata or the holothurian $O$. digitata - are known to support the usually high sedimentation rates (Rhoads et al., 1985). Despite being limited to a single study period (i.e. seasonality cannot be assessed), our data confirm the same biocoenosis to occur all along the studied transect, while we could expect a higher temporal variability in the delta front and the prodelta than in the offshore deep submarine delta (i.e., the Intermediate MDS group).

Benthic assemblages revealed an overall low biodiversity, but were not uniform along the transect. There was a general increasing east-to-west gradient, in parallel with a lowering Rhône influence leading to a relative increase in environmental quality. The 
area closest to the river mouth showed higher species richness, density and diversity to the east (i.e., Close2) than to the west (i.e., Close1), where the M-AMBI qualified as "mediocre" (Bald et al., 2005; Muxika et al., 2007). Such an abrupt decrease was previously correlated with a decrease in OM (Hermand et al., 2008), but could also be attributed to a spatially restricted plume influence, which tends to be mainly orientated westwards. The stations usually avoiding the plume influence, both to the east (short distance from the river) and to the west (long distance to the river), grouped together in our analyses (i.e., Far), showed similar assemblages, and can be considered as dynamic according to TI. On the other hand, as macrobenthic assemblages typically integrate environmental variability through time, some singularities (e.g., around S5), which could be related with punctual, relative differences in resuspension levels (Ulses et al., 2008), were not reflected in assemblage composition and structure.

\subsection{Species distribution modelling}

Our modelling results are in line with the main bibliographical findings: the most reliable models have few feature classes (i.e., linear and quadratic) and use a strong regularization to avoid overfitting (Phillips et al., 2006; Wisz et al., 2008; Shcheglovitova and Anderson, 2013; Radosavljevic et al., 2014). The latter is important because it may lead to increase AUC without necessarily reflecting a high model performance (Pearson et al., 2007; Merow et al., 2013; Boria et al., 2014; GuilleraArroita et al., 2015; Morales et al., 2017; Phillips et al., 2017).

Given the limited number of findings in our dataset, no relevant patterns could be highlighted by MaxEnt for some of the selected species, while others (e.g., S. scutata and $T$. flexuosa) appeared to be more likely distributed on the central and central-eastern parts of the study area. These distributions almost completely overlap with those of the 
stations from Close1 and Close2, and are also coherent with the conditions previously described for the study area (Bonifácio et al., 2014). The suitability of several selected species was positively correlated with the finest granulometric fractions (i.e. silt and/or clay) and with some inorganic variables (e.g., P for the polychaete $S$. scutata), while showing overall negative correlations with fine, medium and medium-coarse sands, as well as with anthracene, PCB118, PCB180 and PCB Tot (particularly in the case of the polychaete $D$. filum). In turn, either Dibenz(a,h)anthracene, Indeno(1,2,3-cd)pyrene or PCB52 provided the biggest amount of information not provided by other variables for almost all species, thus increasing the gain of the overall model. There are no bibliographical data indicating direct relationships between one of these three compounds and the actual distribution of the modelled species and, as mentioned above, such relationships were not evidenced by our classical ecological approach. Therefore, MaxEnt allowed us to provide a different perspective by taking into account the importance of the predictor variables processed by the machine learning algorithm (Elith et al., 2011; Phillips et al., 2017). This confirms its complementarity with traditional benthic assemblage analyses in understanding the factors influencing marine invertebrate distributions (Meißner et al., 2014). Even if no striking patterns have been highlighted in our study case, such a complementarity could otherwise be disregarded, in particular within the framework of environmental impact assessment and conservation strategies.

In summary, considering MaxEnt performance, we believe that our integrated approach - combining traditional statistical analyses on benthic assemblages with the model insights - may contribute to optimize the yield of an environmental impact assessment while providing a robust tool to highlight potential patterns that may remain hidden with a classical approach. Moreover, it definitively contributed to improve our 
knowledge on how river-mediated anthropogenic discharges may influence biodiversity distribution and functional patterns in marine benthic ecosystems.

\section{ACKNOWLEDGEMENTS}

This study has been developed within the framework of the Environmental Impact Assessment for the project "Midi Provence" of the French "Réseau de Transport d'Electricité" and has been partly funded by a research contract between the CEAB and Créocéan. The paper is a contribution of DM to the Consolidated Research Group on Marine Benthic Ecology of the Generalitat de Catalunya (2017SGR378) and to the Research Project PopCOmics (CTM2017-88080), funded by the Spanish "Ministerio de Ciencia, Innovación y Universidades" (MICINU), the "Agencia Española de Investigación" (AEI) and the European Regional Development Funds (FEDER). The authors would like to thank particularly the two anonymous reviewers, whose contributions allowed us to improve the quality and readability of our paper.

\section{REFERENCES}

Alzieu C, Michel LP, Chiffoleau J-F, Boutier B, Abarnou A. Contamination chimique des sédiments. In: Alzieu C, editor. Dragages et environnement marin. Ifremer, Plouzané, 1999, pp. 67-107.

Anderson RP, Gonzalez I. Species-specific tuning increases robustness to sampling bias in models of species distributions: An implementation with Maxent. Ecological Modelling 2011; 222: 2796-2811. 
Audouin JV, Milne Edwards H. Classification des annélides, et description de celles qui habitent les côtes de la France. Annales des Sciences Naturelles, Paris 1833; 28: $187-247$.

Azzurro E, Soto S, Garofalo G, Maynou F. Fistularia commersonii in the Mediterranean Sea: invasion history and distribution modeling based on presenceonly records. Biological Invasions 2013; 15: 977-990.

Bald J, Borja A, Muxika I, Franco J, Valencia V. Assessing reference conditions and physico-chemical status according to the European Water Framework Directive: a case-study from the Basque Country (Northern Spain). Marine Pollution Bulletin 2005; 50: 1508-1522.

Bataille T, Le Guyader C, Simon A. Bilan national du RÉPOM - Réseau national de surveillance de la qualité des eaux et des sédiments des ports maritimes. Brest: CETMEF, 2010.

Beck J, Böller M, Erhardt A, Schwanghart W. Spatial bias in the GBIF database and its effect on modeling species' geographic distributions. Ecological Informatics 2014; 19: $10-15$.

Bernardello R, Serrano E, Coma R, Ribes M, Bahamon N. A comparison of remotesensing sea surface temperature and in situ seawater temperature in near-shore habitats in the western Mediterranean Sea. Marine Ecology Progress Series 2016; 559: 21-34.

Blanchard AL, Feder HM, Shaw DG. Associations between macrofauna and sediment hydrocarbons from treated ballast water effluent at a marine oil terminal in Port Valdez, Alaska. Environmental Monitoring and Assessment 2011; 178: 461-476.

Bonifácio P, Bourgeois S, Labrune C, Amouroux JM, Escoubeyrou K, Buscail R, et al. Spatiotemporal changes in surface sediment characteristics and benthic macrofauna composition off the Rhône River in relation to its hydrological regime. Estuarine, Coastal and Shelf Science 2014; 151: 196-209.

Boria RA, Olson LE, Goodman SM, Anderson RP. Spatial filtering to reduce sampling bias can improve the performance of ecological niche models. Ecological Modelling 2014; 275: 73-77.

Borja A, Franco J, Pérez V. A marine biotic index to establish the ecological quality of soft-bottom benthos within European estuarine and coastal environments. Marine Pollution Bulletin 2000; 40: 1100-1114. 
Bourrin F, Durrieu de Madron X. Contribution to the study of coastal rivers and associated prodeltas to sediment supply in the Gulf of Lions (NW Mediterranean Sea). Vie et Milieu 2006; 56: 307-314.

Bradie J, Leung B. A quantitative synthesis of the importance of variables used in MaxEnt species distribution models. Journal of Biogeography 2017; 44: 1344-1361.

Breiner FT, Guisan A, Nobis MP, Bergamini A. Including environmental niche information to improve IUCN Red List assessments. Diversity and Distributions 2017; 23: 484-495.

Bronn HG. Uebersicht der Fossilen Ueberreste in den tertiären subapenninischen Gebirgen. Italiens Tertiär-Gebilde und deren organische Einschlüsse. Heidelberg: Karl Groos, 1831.

Casado-Martinez MC, Branco V, Vale C, Ferreira AM, Delvalls TA. Is Arenicola marina a suitable test organism to evaluate the bioaccumulation potential of $\mathrm{Hg}$, PAHs and PCBs from dredged sediments? Chemosphere 2008; 70: 1756-65.

Castellón A, Salat J, Masó M. Some observations on Rhone fresh water plume in the Catalan coast. Rapports de la Commission Internationale pour l'Exploration de la Mer Méditerranéene 1984; XXIX.

Claparède É. Les annélides chétopodes du Golfe de Naples. Mémoires de la Société de Physique et d'Histoire Naturelle de Genève 1868; 19: 313-584.

Clarke KR, Gorley RN. PRIMER v6: user manual/tutorial (Plymouth routines in multivariate ecological research). Plymouth: Primer-E Ltd., 2006.

Crafton RE. Modeling invasion risk for coastal marine species utilizing environmental and transport vector data. Hydrobiologia 2015; 746: 349-362.

de Mora S, Villeneuve J-P, Reza Sheikholeslami M, Cattini C, Tolosa I. Organochlorinated compounds in Caspian Sea sediments. Marine Pollution Bulletin 2004; 48: 30-43.

Dufois F, Verney R, Le Hir P, Dumas F, Charmasson S. Impact of winter storms on sediment erosion in the Rhone River prodelta and fate of sediment in the Gulf of Lions (North Western Mediterranean Sea). Continental Shelf Research 2014; 72: $57-72$.

Dumas C, Ludwig W, Aubert D, Eyrolle F, Raimbault P, Gueneugues A, et al. Riverine transfer of anthropogenic and natural trace metals to the Gulf of Lions (NW Mediterranean Sea). Applied Geochemistry 2015; 58: 14-25. 
Durrieu de Madron X, Abassi A, Heussner S, Monaco A, Aloisi JC, Radakovitch O, et al. Particulate matter and organic carbon budgets for the Gulf of Lions (NW Mediterranean). Oceanologica acta 2000; 23: 717-730.

Durrieu de Madron X, Guieu C, Sempéré R, Conan P, Cossa D, D’Ortenzio F, et al. Marine ecosystems' responses to climatic and anthropogenic forcings in the Mediterranean. Progress in Oceanography 2011; 91: 97-166.

Eisig H. Monographie der Capitelliden des Golfes von Neapel und der angrenzenden meeres-abschnitte nebst untersuchungen zur vergleichenden anatomie und physiologie. Fauna und Flora des Golfes von Neapel und der angrenzenden MeeresAbschnitte 1887; 16: xxvi \& 1-906.

Elith J, Graham CH, Anderson RP, Dudik M, Ferrier S, Guisan A, et al. Novel methods improve prediction of species' distributions from occurrence data. Ecography 2006; 29: $129-151$.

Elith J, Phillips SJ, Hastie T, Dudik M, Chee YE, Yates CJ. A statistical explanation of MaxEnt for ecologists. Diversity and Distributions 2011; 17: 43-57.

Estournel C, Kondrachoff V, Marsaleix P, Vehil R. The plume of the Rhone: numerical simulation and remote sensing. Continental Shelf Research 1997; 17: 899-924.

Fauvel P. Annélides Polychètes nouvelles du Maroc. Bulletin de la Société Zoologique de France 1928; 53: 9-13.

Fennel W, Neumann T. Introduction to the modelling of marine ecosystems (with MATLAB programs on accompanying CD-ROM). Vol 72. Amsterdam: Elsevier, 2015

Forbes E. On the radiata of the eastern Mediterranean. Transactions of the Linnean Society of London 1843; 19: 143-153.

Franklin J. Mapping Species Distributions: Cambridge University Press, 2009.

Fraysse M, Pairaud I, Ross ON, Faure VM, Pinazo C. Intrusion of Rhone River diluted water into the Bay of Marseille: Generation processes and impacts on ecosystem functioning. Journal of Geophysical Research: Oceans 2014; 119: 6535-6556.

González-Irusta JM, González-Porto M, Sarralde R, Arrese B, Almón B, Martín-Sosa P. Comparing species distribution models: a case study of four deep sea urchin species. Hydrobiologia 2015; 745: 43-57.

Guillera-Arroita G, Lahoz-Monfort JJ, Elith J, Gordon A, Kujala H, Lentini PE, et al. Is my species distribution model fit for purpose? Matching data and models to applications. Global Ecology and Biogeography 2015; 24: 276-292. 
Guizien K, Belharet M, Moritz C, Guarini JM. Vulnerability of marine benthic metapopulations: implications of spatially structured connectivity for conservation practice in the Gulf of Lions (NW Mediterranean Sea). Diversity and Distributions 2014; 20: 1392-1402.

Harmelin-Vivien ML, Bănaru D, Dierking J, Hermand R, Letourneur Y, Salen-Picard C. Linking benthic biodiversity to the functioning of coastal ecosystems subjected to river runoff (NW Mediterranean). Animal Biodiversity and Conservation 2009; 32: 135-145.

Hermand R, Salen-Picard C, Alliot E, Degiovanni C. Macrofaunal density, biomass and composition of estuarine sediments and their relationship to the river plume of the Rhone River (NW Mediterranean). Estuarine, Coastal and Shelf Science 2008; 79: 367-376.

Holmes KW, Van Niel KP, Radford B, Kendrick GA, Grove SL. Modelling distribution of marine benthos from hydroacoustics and underwater video. Continental Shelf Research 2008; 28: 1800-1810.

Labrune C, Romero-Ramirez A, Amouroux JM, Duchêne JC, Desmalades M, Escoubeyrou K, et al. Comparison of ecological quality indices based on benthic macrofauna and sediment profile images: A case study along an organic enrichment gradient off the Rhône River. Ecological Indicators 2012; 12: 133-142.

Lamarck JB. Histoire naturelle des animaux sans vertèbres, présentant les caractères généraux et particuliers de ces animaux, leur distribution, leurs classes, leurs familles, leurs genres, et la citation des principales espèces qui s'y rapportent; précédée d'une introduction offrant la détermination des caractères essentiels de l’animal, sa distinction du végétal et des autres corps naturels, enfin, l'exposition des principes fondamentaux de la Zoologie. Volume 5. Vol 5. Paris: Déterville \& Verdière, 1818.

Larsen MM, Fryer R. Levels and trends in marine contaminants and their biological effects-CEMP Assement report 2014. OSPAR Commission, 2015.

Long ER, Macdonald DD, Smith SL, Calder FD. Incidence of adverse biological effects within ranges of chemical concentrations in marine and estuarine sediments. Environmental Management 1995; 19: 81-97.

Lorthiois T, Doxaran D, Chami M. Daily and seasonal dynamics of suspended particles in the Rhône River plume based on remote sensing and field optical measurements. Geo-Marine Letters 2012; 32: 89-101. 
Ludwig W, Dumont E, Meybeck M, Heussner S. River discharges of water and nutrients to the Mediterranean and Black Sea: Major drivers for ecosystem changes during past and future decades? Progress in Oceanography 2009; 80: 199-217.

Lynam CP, Uusitalo L, Patrício J, Piroddi C, Queirós AM, Teixeira H, et al. Uses of innovative modeling tools within the implementation of the marine strategy framework directive. Frontiers in Marine Science 2016; 3: 182.

McIntosh WC. A monograph of British Annelids. II. Part I. Polychaeta. Nephthydidae to Syllidae. of London: Ray Society, 1908.

Meißner K, Fiorentino D, Schnurr S, Arbizu PM, Huettmann F, Holst S, et al. Distribution of benthic marine invertebrates at northern latitudes - An evaluation applying multi-algorithm species distribution models. Journal of Sea Research 2014; 85: 241-254.

Merow C, Smith MJ, Silander JA. A practical guide to MaxEnt for modeling species' distributions: what it does, and why inputs and settings matter. Ecography 2013; 36: 1058-1069.

Miller RJ, Juska C, Hocevar J. Submarine canyons as coral and sponge habitat on the eastern Bering Sea slope. Global Ecology and Conservation 2015; 4: 85-94.

Millot C. The Gulf of Lions' hydrodynamics. Continental Shelf Research 1990; 10: 885894.

Millot C. Circulation in the Western Mediterranean Sea. Journal of Marine Systems 1999; 20: 423-442.

Miralles J, Radakovitch O, Aloisi JC. 210Pb sedimentation rates from the Northwestern Mediterranean margin. Marine Geology 2005; 216: 155-167.

Montagu G. Testacea Britannica, or, Natural History of British shells, marine, land, and fresh-water, including the most minute: systematically arranged and embellished with figures. London: J.S. Hollis, 1803.

Montagu G. An account of some new and rare marine British shells and animals. Transactions of the Linnean Society of London 1816; 11: 179-204.

Morales NS, Fernandez IC, Baca-Gonzalez V. MaxEnt's parameter configuration and small samples: Are we paying attention to recommendations? A systematic review. PeerJ 2017; 5: e3093.

Muxika I, Borja A, Bald J. Using historical data, expert judgement and multivariate analysis in assessing reference conditions and benthic ecological status, according 
to the European Water Framework Directive. Marine pollution bulletin 2007; 55: 16-29.

Ollivier P, Radakovitch O, Hamelin B. Major and trace element partition and fluxes in the Rhône River. Chemical Geology 2011; 285: 15-31.

Örsted AS. Annulatorum danicorum conspectus. Fasc. 1 Maricolae. Hafniae: Librariae Wahlianae, 1843.

Oursel B, Garnier C, Zebracki M, Durrieu G, Pairaud I, Omanović D, et al. Flood inputs in a Mediterranean coastal zone impacted by a large urban area: Dynamic and fate of trace metals. Marine Chemistry 2014; 167: 44-56.

Pearson RG, Raxworthy CJ, Nakamura M, Townsend Peterson A. Predicting species distributions from small numbers of occurrence records: a test case using cryptic geckos in Madagascar. Journal of biogeography 2007; 34: 102-117.

Pérès JM, Picard J. Nouveau manuel de bionomie benthique de la mer Mediterranee. Recueil des Travaux de la Station Marine d'Endoume 1964; 31: 1-138.

Phillips SJ. A brief tutorial on Maxent. Available from http://biodiversityinformatics.amnh.org/open_source/maxent/. 2017.

Phillips SJ, Anderson RP, Dudík M, Schapire RE, Blair ME. Opening the black box: an open - source release of Maxent. Ecography 2017; 40: 887-893.

Phillips SJ, Anderson RP, Schapire RE. Maximum entropy modeling of species geographic distributions. Ecological Modelling 2006; 190: 231-259.

Phillips SJ, Dudík M. Modeling of species distributions with Maxent: new extensions and a comprehensive evaluation. Ecography 2008; 31: 161-175.

Pielou EC. An Introduction to Mathematical Ecology. New York: Willey, 1969.

Radakovitch O, Charmasson S, Arnaud M, Bouisset P. 210Pb and Caesium Accumulation in the Rhône Delta Sediments. Estuarine, Coastal and Shelf Science 1999; 48: 77-92.

Radosavljevic A, Anderson RP, Araújo M. Making better Maxent models of species distributions: complexity, overfitting and evaluation. Journal of Biogeography 2014; 41: 629-643.

Ranzani C. Descrizione di una nuova specie del genere Thalassema. Opuscoli Scientifica $1817 ; 1: 112-113$.

Reiss H, Cunze S, König K, Neumann H, Kröncke I. Species distribution modelling of marine benthos: a North Sea case study. Marine Ecology Progress Series 2011; 442: 71-86. 
Rhoads DC, Boesch DF, Zhican T, Fengshan X, Liqiang H, Nilsen KJ. Macrobenthos and sedimentary facies on the Changjiang delta platform and adjacent continental shelf, East China Sea. Continental Shelf Research 1985; 4: 189-213.

Roussiez V, Aloisi J-C, Monaco A, Ludwig W. Early muddy deposits along the Gulf of Lions shoreline: A key for a better understanding of land-to-sea transfer of sediments and associated pollutant fluxes. Marine Geology 2005a; 222-223: 345358.

Roussiez V, Ludwig W, Probst J-L, Monaco A. Background levels of heavy metals in surficial sediments of the Gulf of Lions (NW Mediterranean): An approach based on $133 \mathrm{Cs}$ normalization and lead isotope measurements. Environmental Pollution 2005b; 138: 167-177.

Salen-Picard C, Arlhac D. Long-term changes in a Mediterranean benthic community: Relationships between the polychaete assemblages and hydrological variations of the Rhône River. Estuaries and Coasts 2002; 25: 1121-1130.

Salen-Picard C, Arlhac D, Alliot E. Responses of a Mediterranean soft bottom community to short-term (1993-1996) hydrological changes in the Rhone river. Marine Environmental Research 2003; 55: 409-427.

Salvadó JA, Grimalt JO, López JF, Durrieu de Madron X, Pasqual C, Canals M. Distribution of organochlorine compounds in superficial sediments from the Gulf of Lion, northwestern Mediterranean Sea. Progress in Oceanography 2013; 118: 235-248.

Shannon CE. A mathematical theory of communication. Bell System Technical Journal 1948; 27: 379-423.

Shcheglovitova M, Anderson RP. Estimating optimal complexity for ecological niche models: a jackknife approach for species with small sample sizes. Ecological Modelling 2013; 269: 9-17.

Siron R, Rontani J, Giusti G. Contamination pétrolière de la microcouche de surface du Golfe de Fos-sur-mer (Mer Méditerranéee). International journal of environmental analytical chemistry 1987; 28: 93-104.

Stewart RH. Introduction to physical oceanography. College Station: Texas A \& M University, 2006.

Syfert MM, Joppa L, Smith MJ, Coomes DA, Bachman SP, Brummitt NA. Using species distribution models to inform IUCN Red List assessments. Biological Conservation 2014; 177: 174-184. 
Syvitski JP, Bahr DB. Numerical models of marine sediment transport and deposition. Computers \& Geosciences 2001; 27: 617-618.

Ulses C, Estournel C, Durrieu de Madron X, Palanques A. Suspended sediment transport in the Gulf of Lions (NW Mediterranean): Impact of extreme storms and floods. Continental Shelf Research 2008; 28: 2048-2070.

Vassallo P, Bianchi CN, Paoli C, Holon F, Navone A, Bavestrello G, et al. A predictive approach to benthic marine habitat mapping: Efficacy and management implications. Marine Pollution Bulletin 2018; 131: 218-232.

Warren DL, Seifert SN. Ecological niche modeling in Maxent: the importance of model complexity and the performance of model selection criteria. Ecological Applications 2011;21:335-342.

Webster L, Fryer R, Davies I, Roose P, Moffa C. Background document on CEMP assessment criteria for QSR 2010. Vol OSPAR Publication No 461. London: OSPAR, 2009.

Wisz MS, Hijmans RJ, Li J, Peterson AT, Graham CH, Guisan A, et al. Effects of sample size on the performance of species distribution models. Diversity and Distributions 2008; 14: 763-773.

Word JQ. The infaunal trophic index, a functional approach to benthic community analyses. University of Washington, Washington, 1990, pp. 297.

Yackulic CB, Chandler R, Zipkin EF, Royle JA, Nichols JD, Campbell Grant EH, et al. Presence - only modelling using MAXENT: when can we trust the inferences? Methods in Ecology and Evolution 2013; 4: 236-243.

Zar JH. Biostatistical Analyses. New Jersey: Prentice Hall International, 1984. 
Figure 1.- Study area and location of the stations of the transect. Data from SIO, NOAA, U.S. Navy, NGA, GEBCO (C) Google, (C) 2009 GeoBasis-DE/BKG, Image Landstad / Copernicus.
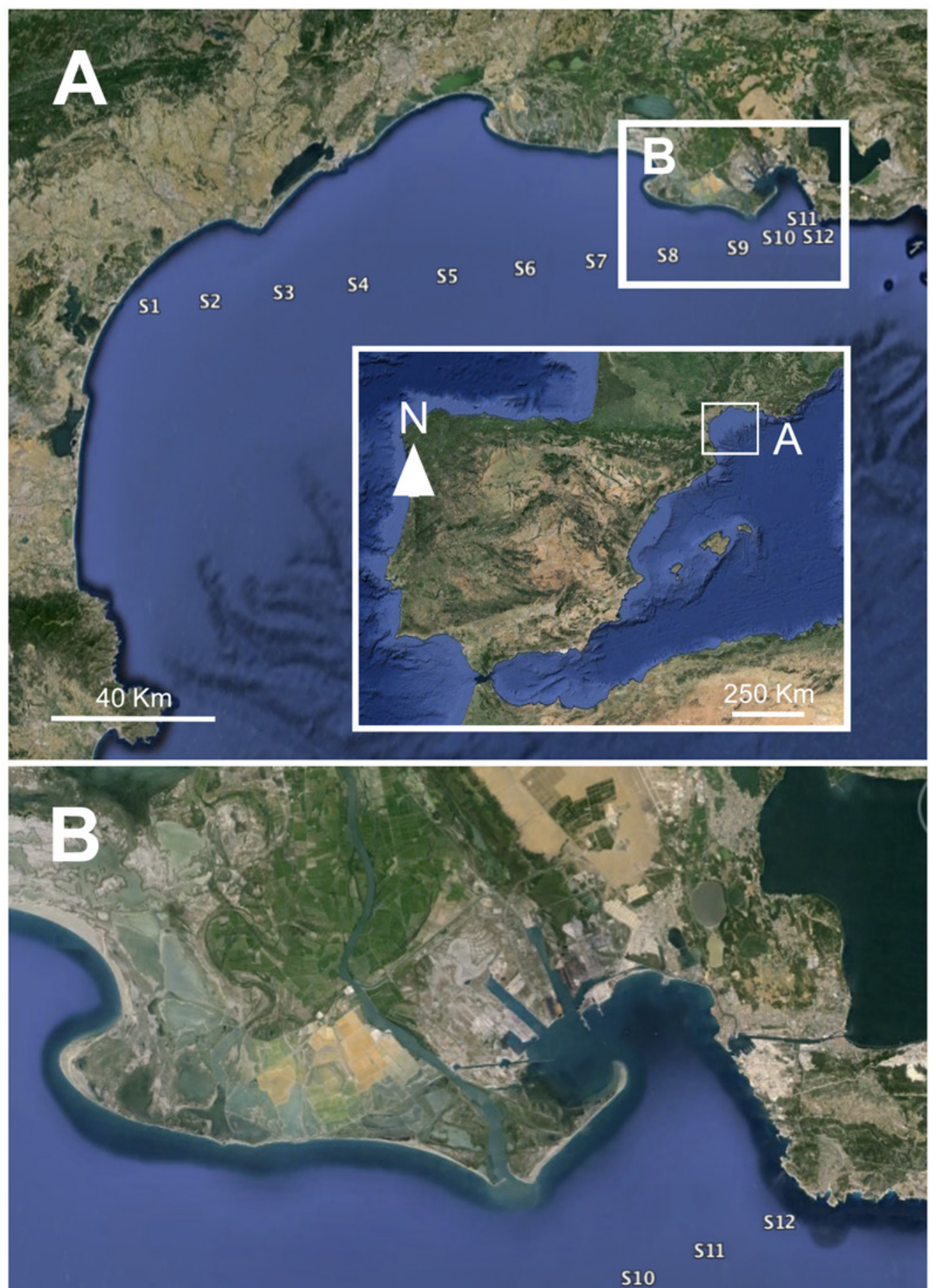

S9 
Figure 2.- Environmental variables along the studied transect: A. Depth (m); B. Clay (< $2 \mu \mathrm{m})$; C. Silt $(2-63 \mu \mathrm{m}) ; \mathrm{D}$. Very fine sands $(64-160 \mu \mathrm{m})$; E. Fine sands $(160-250$ $\mu \mathrm{m})$; F. Medium sands (250 - $500 \mu \mathrm{m})$; G. PW, Pore water (\%); H. OM, Organic matter (\%); I. OC, Organic carbon (\%); J. N, Nitrogen (mg/L); J. P, Phosphorus (mg/Kg).

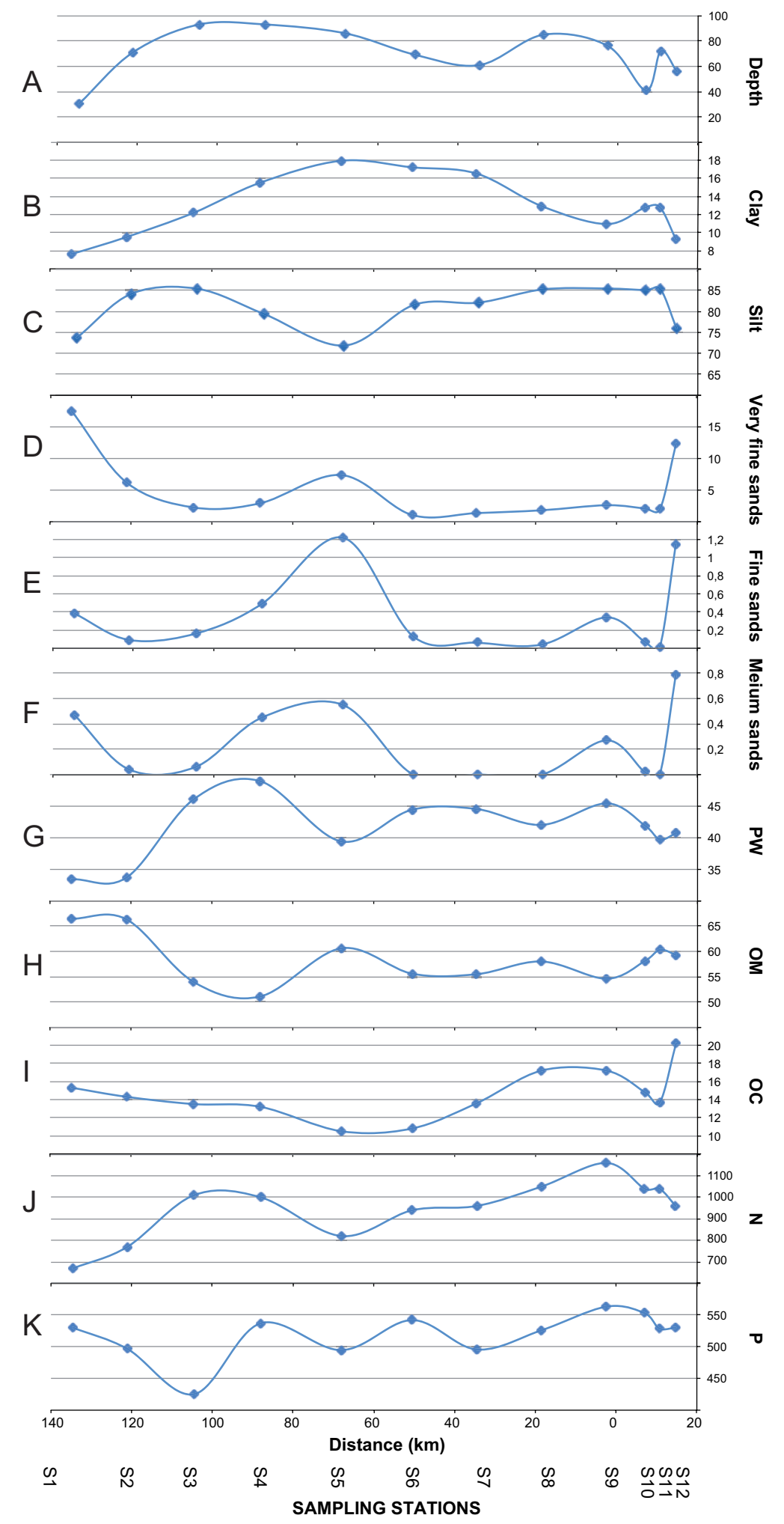


Figure 3.- Environmental variables along the studied transect. Metal contents $(\mathrm{mg} / \mathrm{Kg})$ : A. Al, Aluminum; B. Ar, Arsenic; C. Cd, Cadmium; D. Cr, Chrome; E. Cu, Copper; F. Fe, Iron; G. Hg, Mercury; H. Ni, Nickel; I. Pb, Lead; J. Zn, Zinc.

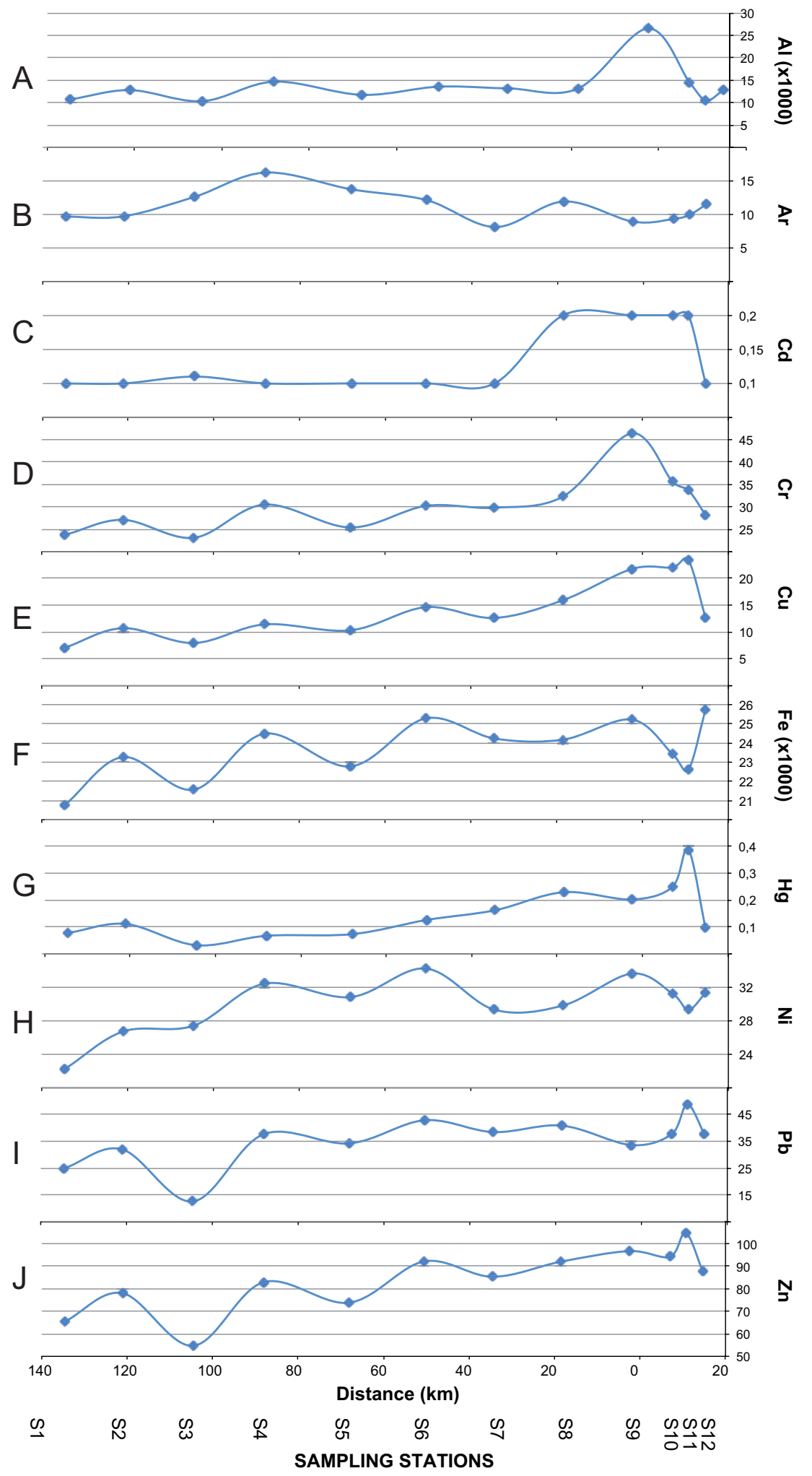


Figure 4.- Environmental variables along the studied transect. Organic pollutants $(\mu \mathrm{g} / \mathrm{Kg})$ : A. HYDs, hydrocarbons; B. PAHs, polycyclic aromatic hydrocarbons; C. PCBs, polychlorinated biphenyls. Water surface variables: D. Chl-a, chlorophyll-a $\left(\mathrm{mg} / \mathrm{m}^{3}\right)$; E. POC, particulate organic matter $\left(\mathrm{mg} / \mathrm{m}^{3}\right)$; F. TEMP, sea surface temperature $\left({ }^{\circ} \mathrm{C}\right)$.

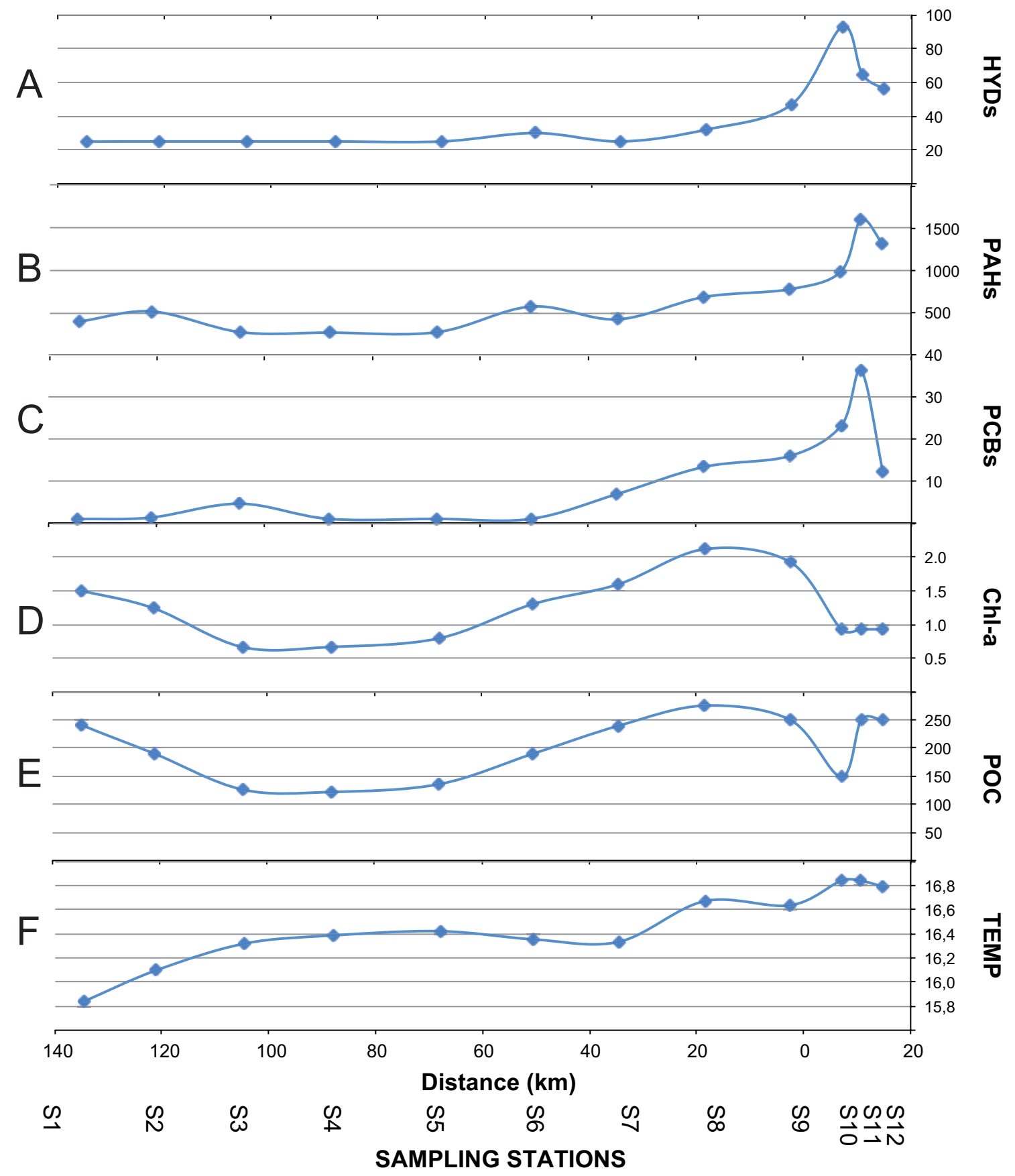


Figure 5.- Assemblage descriptors along the studied transect: A. Species richness (species - sample); B. Density (ind $\left./ \mathrm{m}^{2}\right)$; C. Biomass $\left(\mathrm{mg} / \mathrm{m}^{2}\right)$; D. Diversity (bits); E. Evenness (\%); F. TI, Trophic index (\%); G. AMBI; H. M- AMBI.

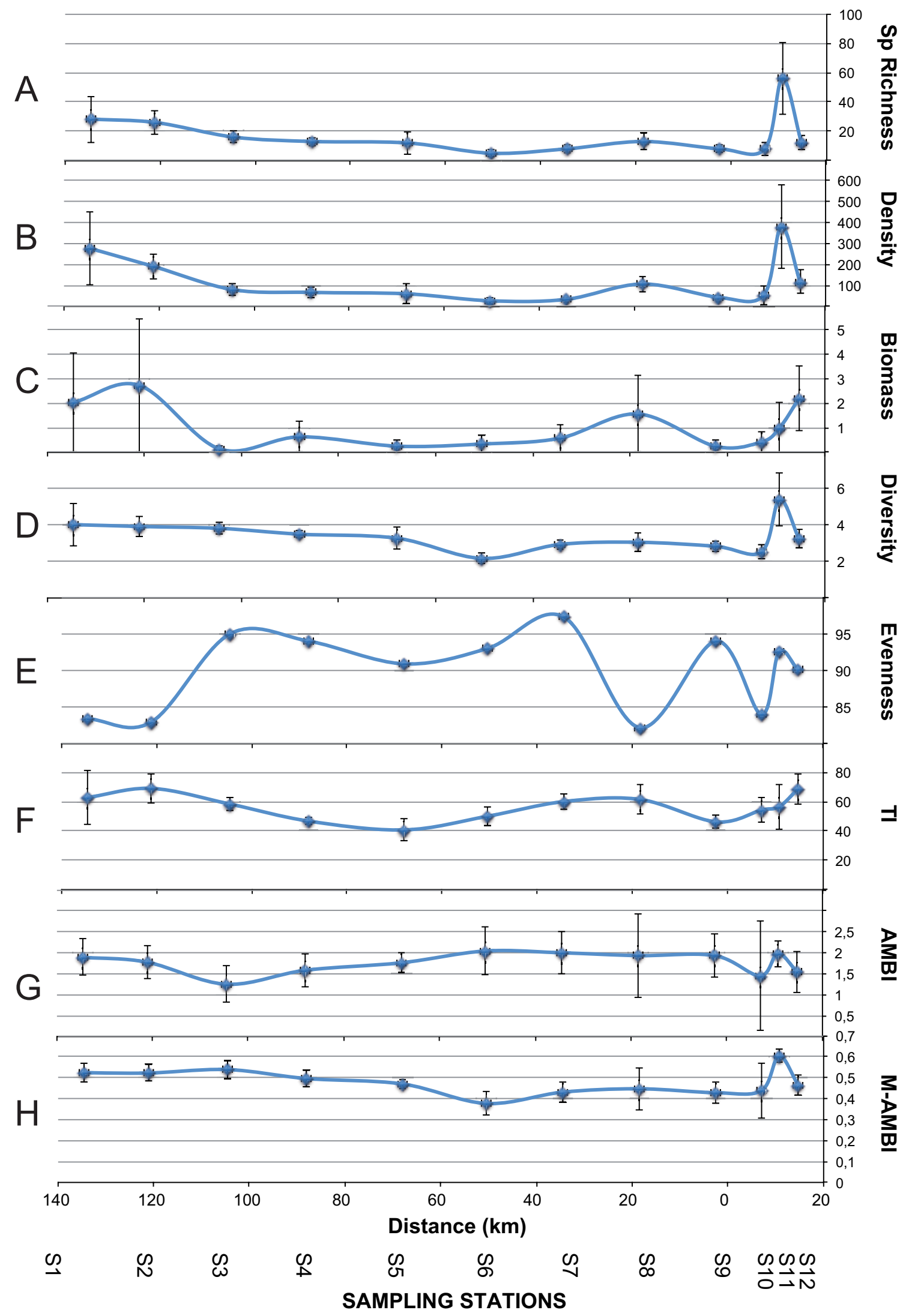


Figure 6.- MDS plots. A. Based on the environmental variables. B. Based on environmental variables and assemblage descriptors. C. Based on the species per sample matrix.

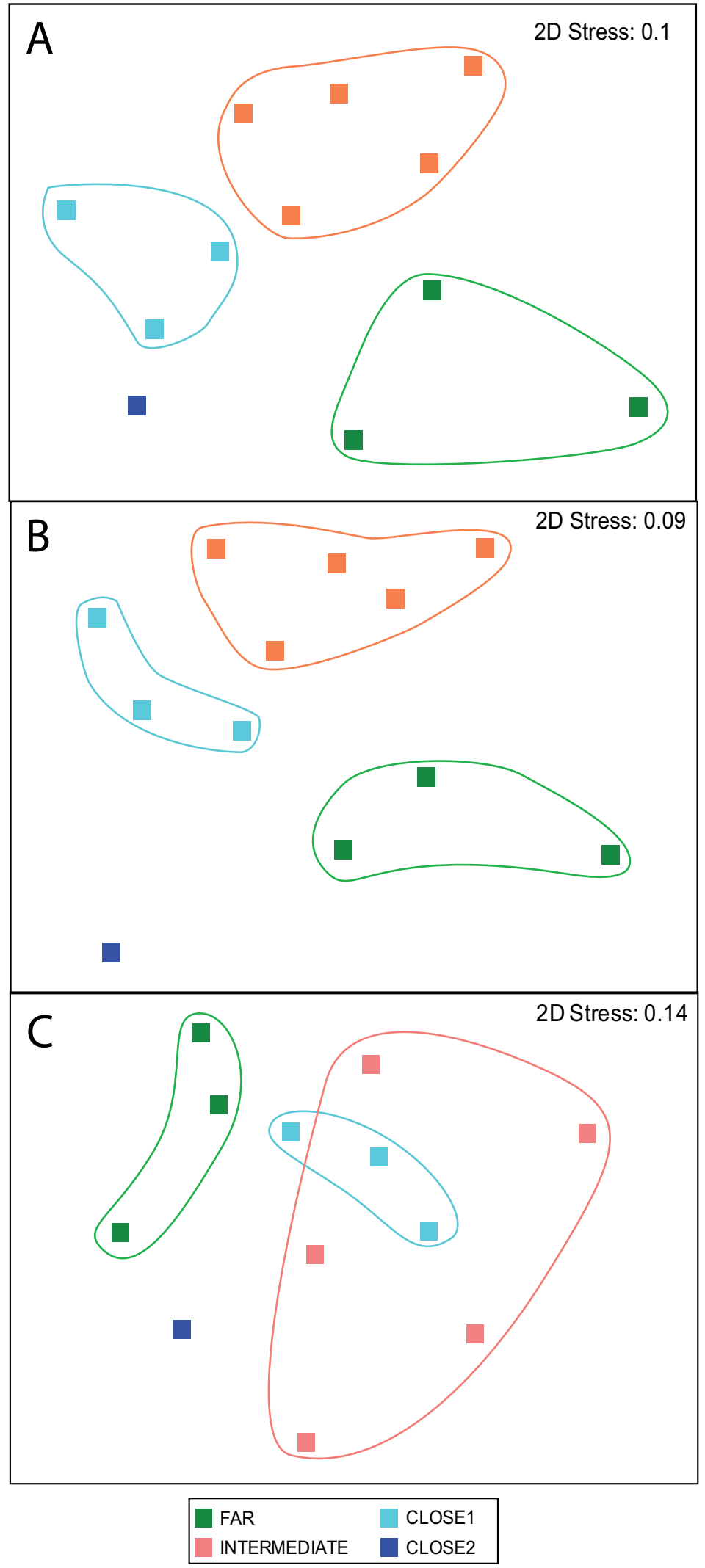


Figure 7.- Boxplots showing the environmental variables characterizing the groups of stations obtained in the MDS: A. Distance to river mouth $(\mathrm{km})$; B. Depth $(\mathrm{m})$. C. Clay $(<2 \mu \mathrm{m})$; D. Silt $(2-63 \mu \mathrm{m})$; E. Very fine sands $(64-160 \mu \mathrm{m}) ; \mathrm{F}$. Fine sands $(160-$ $250 \mu \mathrm{m}) ; \mathrm{G}$. Medium sands $(250-500 \mu \mathrm{m}) ; \mathrm{H}$. Pore water (\%); I. Organic matter (\%); J. Organic carbon (\%); K. Nitrogen (mg/L); L. Phosphorus (mg/kg); M. Chlorophyll-a $\left(\mathrm{mg} / \mathrm{m}^{3}\right) ;$ N. Particulate organic matter $\left(\mathrm{mg} / \mathrm{m}^{3}\right) ;$ O. Sea surface temperature $\left({ }^{\circ} \mathrm{C}\right)$.

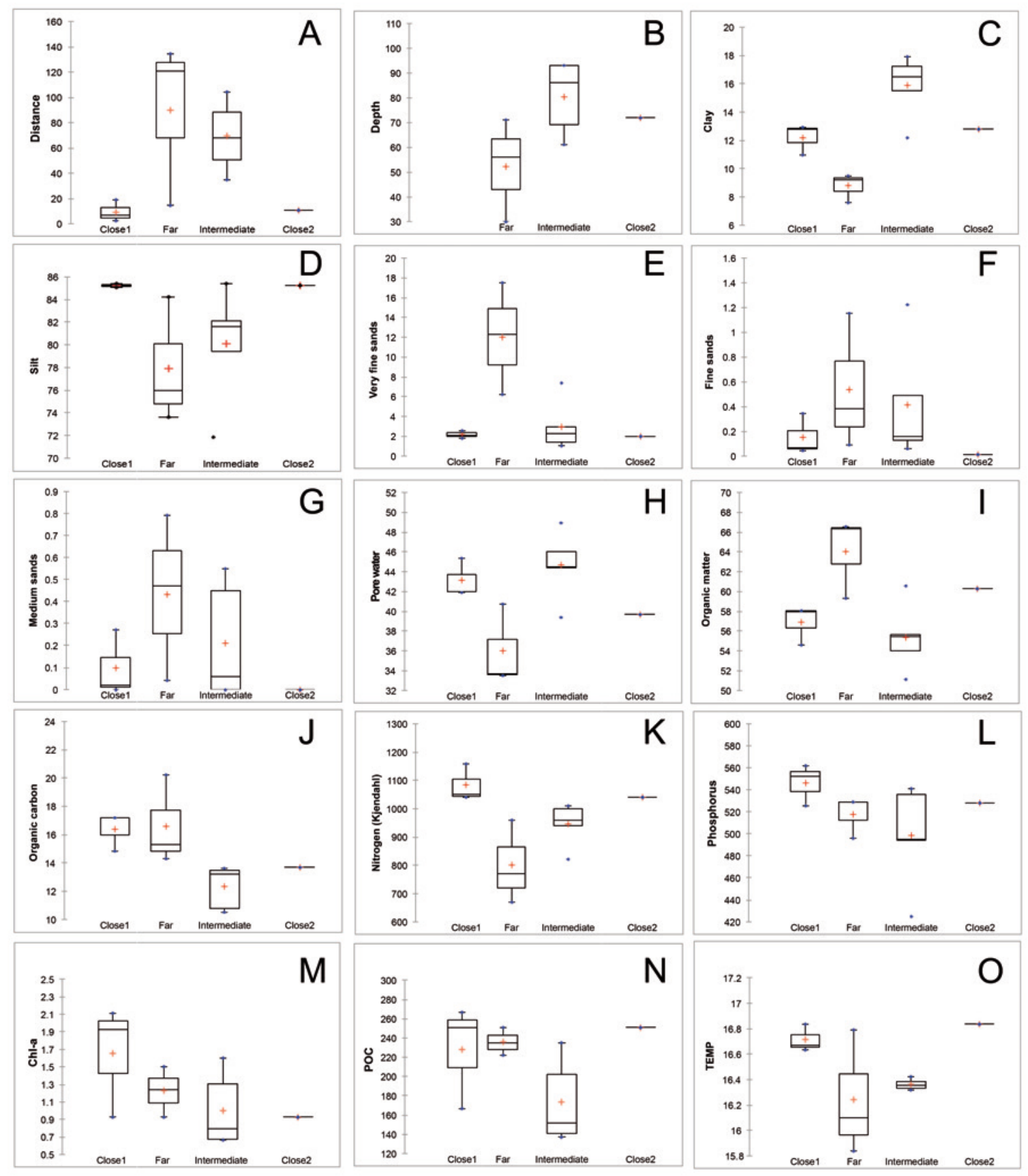


Figure 8.- Boxplots showing the environmental variables characterizing the groups of stations obtained in the MDS. Metal contents $(\mathrm{mg} / \mathrm{Kg})$ : A. Aluminium; B. Arsenic; C. Iron; D. Chrome; E. Copper; F. Mercury; G. Cadmium; H. Lead; I. Nickel; J. Zinc. Organic pollutants: $(\mu \mathrm{g} / \mathrm{Kg})$ : K. HYDs, hydrocarbons; L. PAHs, polycyclic aromatic hydrocarbons; M. PCBs, polychlorinated biphenyls.

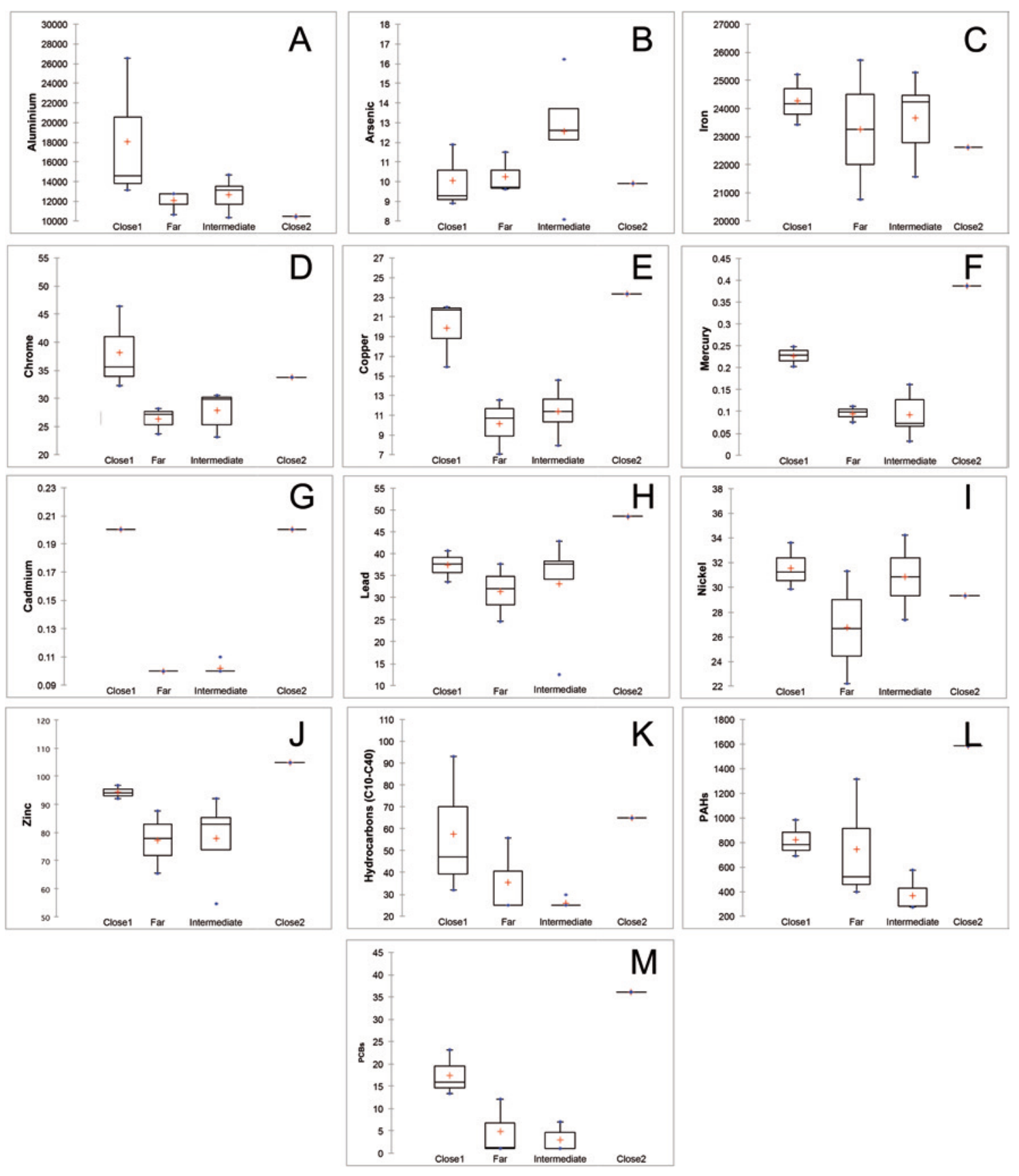


Figure 9.- Boxplots showing the assemblage descriptors characterizing the groups of stations obtained in the MDS. A. Species richness (species x sample); B. Density (ind $\left./ \mathrm{m}^{2}\right)$; C. Diversity (bits); D. Evenness (\%); E. Biomass $\left(\mathrm{mg} / \mathrm{m}^{2}\right)$; F. TI, Trophic index (\%); G. AMBI; H. M-AMBI.
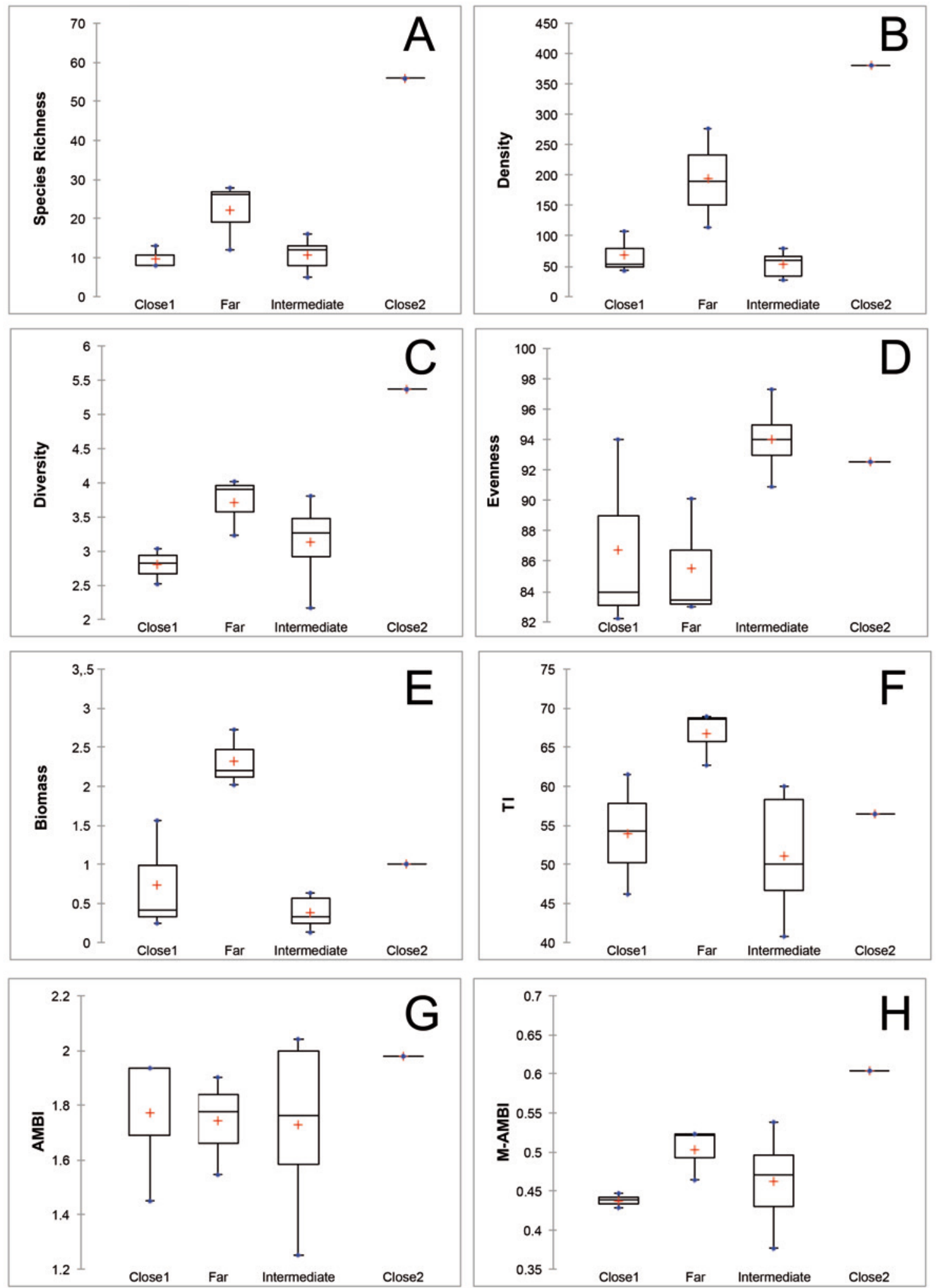
Figure 10.- Representation of the MaxEnt model for the distribution of the target species.

\section{A Sternaspis scutata}

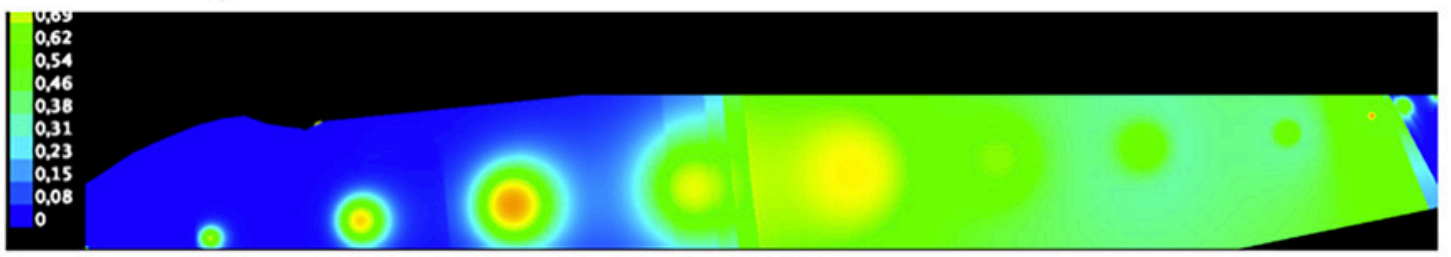

\section{B Driloneris filum}

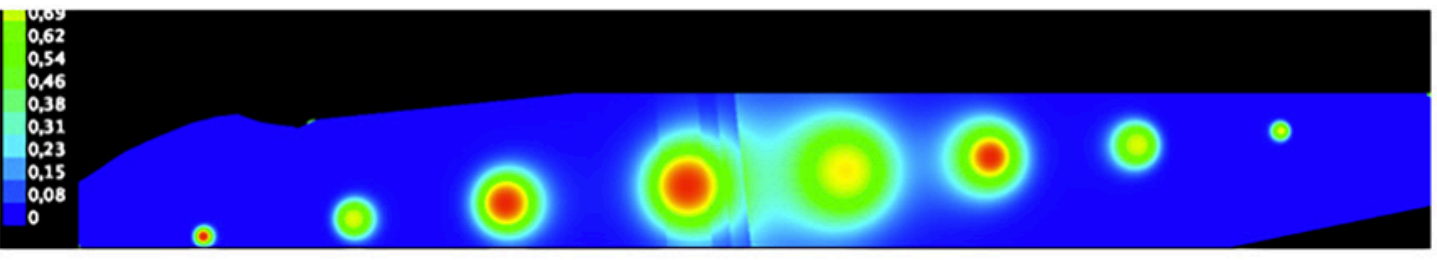

\section{Glycera unicornis}

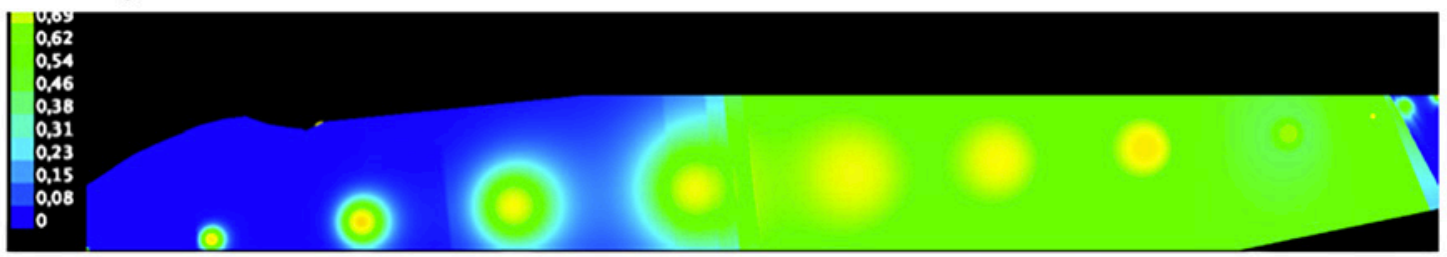

\section{Nucula sulcata}

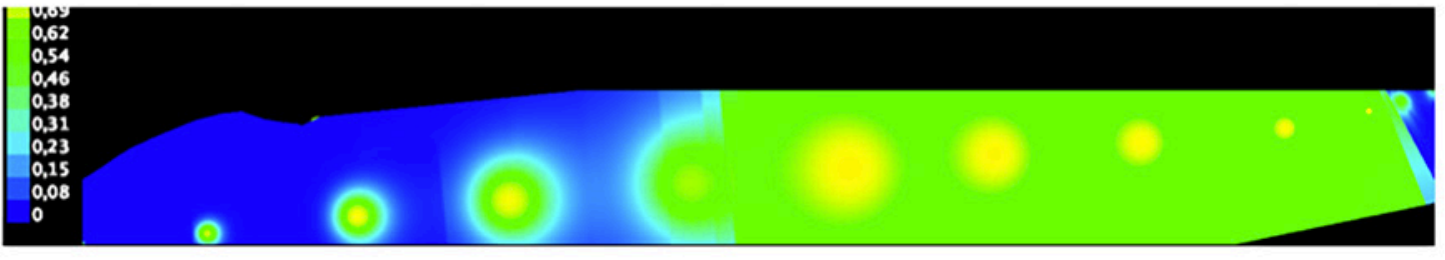

\section{E Thyasira flexuosa}

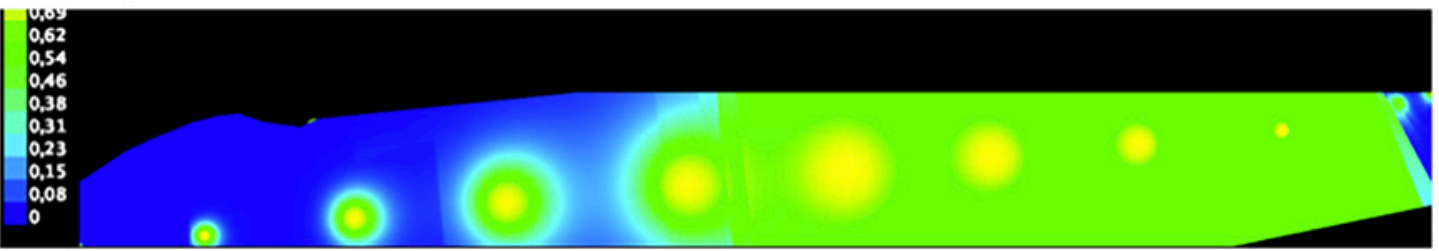


Figure 11.- Jack-knife test of variable importance on the average model for Sternapsis scutata. Values shown are averages over replicate runs.

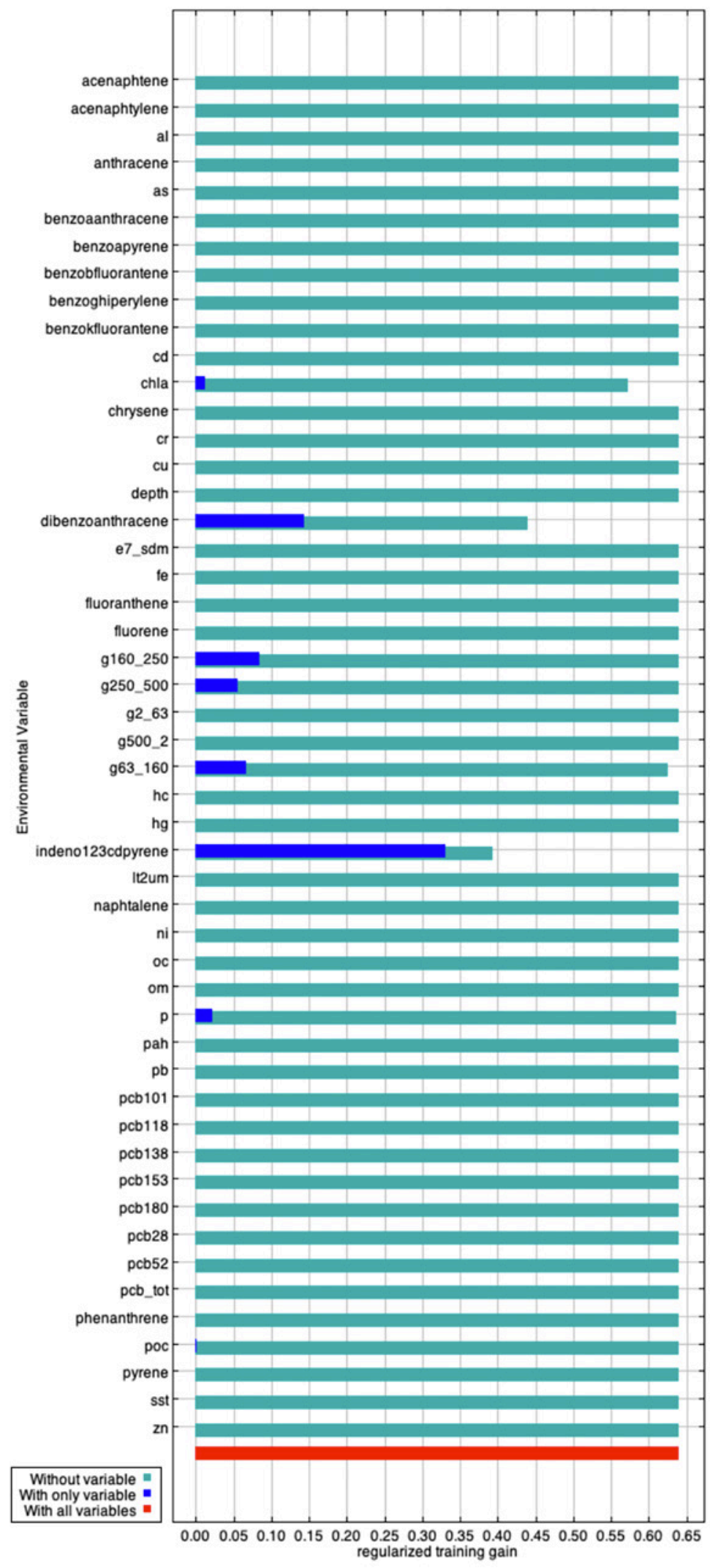


Table 1. List of physical-chemical parameters analysed in the sampled sediments. DS: Dry sediment; DW: dry weight.

\begin{tabular}{|c|c|c|c|c|}
\hline Parameter & $\begin{array}{l}\text { Abbrevi } \\
\text { ation }\end{array}$ & Units & Method & Norm \\
\hline Sediments & & $\begin{array}{l}\text { \% DS } \\
\text { Volu } \\
\text { me }\end{array}$ & $\begin{array}{l}\text { Malvern Mastersizer S laser } \\
\text { granulometer }\end{array}$ & NF ISO 13320-1 \\
\hline Pore water content & PW & $\%$ & Centrifugation & AFNOR standard X 31-102 \\
\hline Total organic matter & $\mathrm{OM}$ & $\begin{array}{l}\% \\
\text { DW }\end{array}$ & Steam-drying at $105^{\circ} \mathrm{C}$ & NF ISO 11465 \\
\hline Organic carbon & $\mathrm{OC}$ & $\begin{array}{l}\mathrm{g} / \mathrm{Kg} \\
\mathrm{DW}\end{array}$ & Combustion & NF ISO 14235 \\
\hline $\begin{array}{l}\text { Kjeldahl Nitrogen in } \\
\text { pore water }\end{array}$ & $\mathrm{N}$ & $\mathrm{mg} / \mathrm{l}$ & Distillation & NF EN 25663 \\
\hline Escherichia coli & & cell/g & $\begin{array}{l}\text { Microplates; miniaturized } \\
\text { method by seeding in liquid } \\
\text { medium }\end{array}$ & XP X33-019 \\
\hline Enterococci & & cell/g & $\begin{array}{l}\text { Microplates; miniaturized } \\
\text { method by seeding in liquid } \\
\text { medium }\end{array}$ & NF EN ISO 7899-1 \\
\hline Total Phosphorous & $\mathrm{P}$ & $\begin{array}{l}\mathrm{mg} / \mathrm{K} \\
\mathrm{g} \mathrm{DW}\end{array}$ & $\begin{array}{l}\text { microwave digestion with } \\
\mathrm{HCl} / \mathrm{HNO}_{3} \\
\text { Inductively Coupled Plasma- } \\
\text { Atomic Emission } \\
\text { Spectrometry }\end{array}$ & $\begin{array}{l}\text { NF EN } 13346 \text { part C } \\
\text { ICP/AES, EN ISO 13346, } \\
\text { NF EN ISO 17294-2 }\end{array}$ \\
\hline Metals & & $\begin{array}{l}\mathrm{mg} / \mathrm{K} \\
\mathrm{g} \mathrm{DW}\end{array}$ & $\begin{array}{l}\text { microwave digestion with } \\
\mathrm{HCl} / \mathrm{HNO}_{3} \\
\text { Inductively Coupled Plasma- } \\
\text { Atomic Emission } \\
\text { Spectrometry }\end{array}$ & $\begin{array}{l}\text { NF EN } 13346 \text { part C } \\
\text { ICP/AES, EN ISO 13346, } \\
\text { NF EN ISO 17294-2 }\end{array}$ \\
\hline $\begin{array}{l}\text { Hydrocarbon, C10- } \\
\text { C14 index }\end{array}$ & HYD & $\begin{array}{l}\mathrm{mg} / \mathrm{K} \\
\mathrm{g} \mathrm{DW}\end{array}$ & $\begin{array}{l}\text { Gas Chromatography after } \\
\text { extraction with accelerated } \\
\text { solvent }\end{array}$ & $\begin{array}{l}\text { CARSON's internal } \\
\text { method based on M_ST061 } \\
\text { Version } 3\end{array}$ \\
\hline $\begin{array}{l}\text { Polycyclic Aromatic } \\
\text { Hydrocarbons }\end{array}$ & PAHs & $\begin{array}{l}\mu \mathrm{g} / \mathrm{K} \\
\mathrm{g} \mathrm{DW}\end{array}$ & $\begin{array}{l}\text { High Performance Liquid } \\
\text { Chromatography using } \\
\text { Fluorescent Detection after } \\
\text { extraction with accelerated } \\
\text { solvent }\end{array}$ & XP X33-012 \\
\hline $\begin{array}{l}\text { Polychlorinated } \\
\text { Biphenyls }\end{array}$ & PCBs & $\begin{array}{l}\mathrm{mg} / \mathrm{K} \\
\mathrm{g} \mathrm{DW}\end{array}$ & $\begin{array}{l}\text { GC/MS after extraction with } \\
\text { accelerated solvent }\end{array}$ & XP X33-012 \\
\hline $\begin{array}{l}\text { Organochlorine } \\
\text { pesticides, } \\
\text { organophosphorus } \\
\text { pesticides and anilines }\end{array}$ & & $\begin{array}{l}\mu \mathrm{g} / \mathrm{K} \\
\mathrm{g} \mathrm{DW}\end{array}$ & GC/MS & $\begin{array}{l}\text { CARSON's internal } \\
\text { method based on XP X33- } \\
012\end{array}$ \\
\hline Dioxins & & $\begin{array}{l}\mathrm{ng} / \mathrm{K} \\
\mathrm{g} \mathrm{DW}\end{array}$ & High Resolution GC/MS & EPA 1613 \\
\hline $\begin{array}{l}\text { Brominated diphenyl } \\
\text { ethers }\end{array}$ & & $\begin{array}{l}\mathrm{ng} / \mathrm{K} \\
\mathrm{g} \mathrm{DW}\end{array}$ & High Resolution GC/MS & EPA 1614 \\
\hline $\begin{array}{l}\text { Chlorophenols and } \\
\text { Alkylphenols }\end{array}$ & & $\begin{array}{l}\mu \mathrm{g} / \mathrm{K} \\
\mathrm{g} \mathrm{DW}\end{array}$ & $\begin{array}{l}\text { GC/MS after extraction with } \\
\text { accelerated solvent } / \mathrm{CH}_{2} \mathrm{CL}_{2}\end{array}$ & $\begin{array}{l}\text { CARSON's internal } \\
\text { method }\end{array}$ \\
\hline $\begin{array}{l}\text { Hexabromocyclododec } \\
\text { ane and } \\
\text { Tetrabromobisphenol- } \\
\text { A }\end{array}$ & & $\begin{array}{l}\mu \mathrm{g} / \mathrm{K} \\
\mathrm{g} \mathrm{DW}\end{array}$ & $\mathrm{GC} / \mathrm{MS}$ & $\begin{array}{l}\text { CARSON's internal } \\
\text { method }\end{array}$ \\
\hline Organotins & & $\begin{array}{l}\mathrm{g} / \mathrm{Kg} \\
\mathrm{DW}\end{array}$ & $\begin{array}{l}\text { GC/MS after liquid-liquid } \\
\text { extraction with hexane }\end{array}$ & XР T90-250 \\
\hline Total tins & & $\begin{array}{l}\mathrm{mg} / \mathrm{K} \\
\mathrm{g} \mathrm{DW}\end{array}$ & $\begin{array}{l}\text { microwave digestion with } \\
\mathrm{HCl} / \mathrm{HNO}_{3}\end{array}$ & NF EN 13346 part C \\
\hline
\end{tabular}


Table 2. Reference levels for trace metals: N1: OSPAR and French regulation threshold for sediment dredging; Background: Known OSPAR background levels; Ecotox: Ecotoxicological criteria.

\begin{tabular}{lccc}
\hline Metals (mg/kg DW) & N1 & Background & Ecotox \\
\hline $\mathrm{Ar}$ & 25 & 15 & - \\
$\mathrm{Cd}$ & 1.2 & 0.2 & 1,2 \\
$\mathrm{Cr}$ & 90 & 60 & 81 \\
$\mathrm{Cu}$ & 45 & 20 & 34 \\
$\mathrm{Hg}$ & 0.4 & 0.05 & 0.15 \\
$\mathrm{Ni}$ & 37 & 30 & - \\
$\mathrm{Pb}$ & 100 & 25 & 47 \\
$\mathrm{Zn}$ & 276 & 90 & 150 \\
\hline
\end{tabular}

Table 3.- Emerging contaminants analysed at stations S1, S3, S5, S8 and S10. Those overpassing the levels of detection are marked in bold.

\begin{tabular}{lcccccc}
\hline & Units & $\mathrm{S} 1$ & $\mathrm{~S} 3$ & $\mathrm{~S} 5$ & $\mathrm{~S} 8$ & $\mathrm{~S} 10$ \\
\hline 4,4' DDT & $\mu \mathrm{g} / \mathrm{kg}$ & 1 & $\mathbf{4 0}$ & $\mathbf{1}$ & $\mathbf{3 6}$ & $\mathbf{3 3}$ \\
1,2,3,4,6,7,8-Heptachlorodibenzodioxine & $\mathrm{ng} / \mathrm{kg}$ & 0.4 & $\mathbf{0 . 6 0 5}$ & $\mathbf{0 . 5 2 4}$ & $\mathbf{0 . 7 7 4}$ & $\mathbf{0 . 6 5 7}$ \\
2,3,7,8-Tétrachlorodibenzofurane & $\mathrm{ng} / \mathrm{kg}$ & $\mathbf{0 . 2 0 5}$ & $\mathbf{0 . 1 8 8}$ & $\mathbf{0 . 1 1 1}$ & $\mathbf{0 . 1 2 6}$ & $\mathbf{0 . 2 7 8}$ \\
Octachlorodibenzodioxine & $\mathrm{ng} / \mathrm{kg}$ & 4 & $\mathbf{7 . 0 0 7}$ & $\mathbf{5 . 3 6 5}$ & $\mathbf{8 . 5}$ & $\mathbf{6 . 9 2 8}$ \\
Sum of the octa BDE 194-205 860 & $\mathrm{ng} / \mathrm{kg}$ & 30 & $\mathbf{7 1}$ & $\mathbf{8 6 0}$ & $\mathbf{1 3 0}$ & $\mathbf{5 3}$ \\
Total tin & $\mathrm{mg} / \mathrm{kg}$ & $\mathbf{0 . 5 8}$ & $\mathbf{0 . 5 9}$ & $\mathbf{0 . 2 7}$ & $\mathbf{0 . 6 9}$ & $\mathbf{3 . 0 7}$ \\
\hline
\end{tabular}


Table 4. Significant correlations between benthic assemblage descriptors and environmental variables. PC: Pearson correlation coefficient; $p$ : probability.

\begin{tabular}{|c|c|c|c|c|c|c|c|c|c|c|c|c|c|c|c|c|}
\hline & \multicolumn{2}{|c|}{ Silt } & \multicolumn{2}{|c|}{$\begin{array}{c}\text { Very fine } \\
\text { sands }\end{array}$} & \multicolumn{2}{|c|}{$\begin{array}{l}\text { Pore } \\
\text { water }\end{array}$} & \multicolumn{2}{|c|}{$\begin{array}{l}\text { Organic } \\
\text { matter }\end{array}$} & \multicolumn{2}{|c|}{$\begin{array}{l}\text { Organic } \\
\text { carbon }\end{array}$} & \multicolumn{2}{|c|}{$\mathrm{Fe}$} & \multicolumn{2}{|c|}{$\mathrm{Ni}$} & \multicolumn{2}{|c|}{$\mathrm{Pb}$} \\
\hline & $\mathrm{PC}$ & $p$ & $\mathrm{PC}$ & $p$ & PC & $p$ & PC & $p$ & $\mathrm{PC}$ & $p$ & $\mathrm{PC}$ & $p$ & PC & $p$ & PC & $p$ \\
\hline Dens & & & & & 0,6 & $<0$. & 0,6 & $<0$ & & & & & 0,6 & $<0$ & & \\
\hline ity & & & & & 34 & 03 & 34 & 03 & & & & & 06 & 04 & & \\
\hline Biom & 0,6 & $<0$. & 0,6 & $<0$ & 0,7 & $<0$. & 0,7 & $<0$. & & & & & & & & \\
\hline ass & 94 & 02 & 10 & 04 & 36 & 01 & 36 & 01 & & & & & & & & \\
\hline Even & & & & & 0,7 & $<0$. & 0,7 & $<0$ & & & 0,5 & $<0$ & & & & \\
\hline ess & 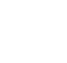 & & & & 00 & 01 & 00 & 01 & & & 83 & 05 & 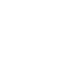 & & & \\
\hline & 0,6 & $<0$ & & & & & & & 0,5 & $<0$. & & & 0,5 & $<0$ & & \\
\hline TI & 76 & 02 & & & & & & & 66 & 05 & & & 73 & 05 & & \\
\hline AMB & & & & & & & & & & & & & & & 0,5 & $<0$. \\
\hline I & & & & & & & & & & & & & & & 83 & 05 \\
\hline M- & & & & & & & & & & & - & & - & & & \\
\hline AMB & & & & & & & & & & & 0,6 & $<0$ & 0,6 & $<0$ & & \\
\hline I & & & & & & & & & & & 68 & 02 & 01 & 04 & & \\
\hline
\end{tabular}


Table 5. Species contributions $(\%>5 \%)$ to the internal similarity for the groups obtained in the MDS according to PRIMER analysis (average similarity indicated between brackets). Av.value: average value; Av.Sim: average similarity; Sim/SD: similarity divided by standard deviation; Contrib\%: percentage of contribution; Cum.\%: cumulative percentage of contribution.

\begin{tabular}{|c|c|c|c|c|c|}
\hline & Av.value & Av.Sim & $\mathrm{Sim} / \mathrm{SD}$ & Contrib\% & Cum.\% \\
\hline \multicolumn{6}{|l|}{ Far $(23.28 \%)$} \\
\hline Sternaspis scutata & 24.44 & 6.14 & 0.84 & 26.38 & 26.38 \\
\hline Oestergrenia digitata & 22.22 & 5.18 & 0.74 & 22.24 & 48.63 \\
\hline Notomastus cf. lineatus & 13.33 & 4.3 & 0.93 & 18.49 & 67.12 \\
\hline Thysiara flexuosa & 10 & 2.13 & 0.57 & 9.14 & 76.25 \\
\hline Apseudopsis cf. acutifrons & 20 & 1.19 & 0.37 & 5.13 & 81.38 \\
\hline \multicolumn{6}{|l|}{ Intermediate $(8.71 \%)$} \\
\hline Sternaspis scutata & 10 & 2.65 & 0.33 & 30.42 & 30.42 \\
\hline Nephtys kersivalensis & 3.75 & 1.47 & 0.2 & 16.92 & 47.34 \\
\hline Marphysa bellii & 3.75 & 1.03 & 0.29 & 11.87 & 59.2 \\
\hline Corbula gibba & 1.88 & 0.51 & 0.16 & 5.87 & 65.08 \\
\hline Thysiara flexuosa & 1.88 & 0.49 & 0.16 & 5.6 & 70.68 \\
\hline Ninoe armoricana & 3.13 & 0.45 & 0.23 & 5.19 & 75.87 \\
\hline \multicolumn{6}{|l|}{ Close1 (14.87\%) } \\
\hline Sternaspis scutata & 12.5 & 9 & 0.69 & 61.38 & 61.38 \\
\hline Glycera unicornis & 6.25 & 1.9 & 0.34 & 12.94 & 74.32 \\
\hline Alpheus glaber & 2.5 & 0.89 & 0.19 & 6.09 & 80.41 \\
\hline Unidentified ophiuroid & 3.75 & 0.89 & 0.19 & 6.09 & 86.5 \\
\hline \multicolumn{6}{|l|}{ Close2 (18.47) } \\
\hline Aponuphis ornata & 20 & 3.8 & 1.68 & 20.57 & 20.57 \\
\hline Glycera unicornis & 20 & 2.74 & 4.36 & 14.84 & 35.42 \\
\hline Levinsenia sp.1 & 30 & 2.74 & 4.36 & 14.84 & 50.26 \\
\hline Eunice vittata & 23.33 & 1.35 & 0.58 & 7.29 & 57.55 \\
\hline Marphysa bellii & 6.67 & 1.06 & 0.58 & 5.73 & 63.28 \\
\hline Heterospio sp. & 20 & 1.06 & 0.58 & 5.73 & 69.01 \\
\hline Lumbrineris latreilli & 13.33 & 1.01 & 0.58 & 5.47 & 74.48 \\
\hline Euclymene sp. & 6.67 & 1.01 & 0.58 & 5.47 & 79.95 \\
\hline Nuculana pella & 6.67 & 1.01 & 0.58 & 5.47 & 85.42 \\
\hline
\end{tabular}


Table 6. Species contributions $((\%>5 \%)$ to the dissimilarity between the groups obtained in the MDS according to PRIMER analysis (average dissimilarity indicated between brackets). Av.value: Average values for the two compared groups; Av.Dis: average dissimilarity; Dis/SD: dissimilarity divided by standard deviation; Contrib\%: percentage of contribution; Cum.\%: cumulative percentage of contribution.

\begin{tabular}{|c|c|c|c|c|c|c|}
\hline Far / Intermediate $(90.80 \%)$ & Av.value & Av. value & Av.Dis & Dis/SD & Contrib\% & Cum.\% \\
\hline Sternaspis scutata & 24.44 & 10 & 11.06 & 1.06 & 12.18 & 12.18 \\
\hline Oestergrenia digitata & 22.22 & 1.88 & 9.37 & 1.12 & 10.32 & 22.49 \\
\hline Notomastus cf. lineatus & 13.33 & 0 & 6.19 & 1.22 & 6.82 & 29.31 \\
\hline Apseudopsis cf. acutifrons & 20 & 0.63 & 5.57 & 0.73 & 6.14 & 35.45 \\
\hline Leptocheirus mariae & 20 & 0 & 4.78 & 0.59 & 5.26 & 40.71 \\
\hline Thysiara flexuosa & 10 & 1.88 & 4.66 & 0.87 & 5.13 & 45.84 \\
\hline \multicolumn{7}{|l|}{ Far / Close1 $(87.51 \%)$} \\
\hline Oestergrenia digitata & 22.22 & 7.5 & 9.9 & 1.15 & 11.32 & 11.32 \\
\hline Sternaspis scutata & 24.44 & 12.5 & 9.56 & 0.99 & 10.92 & 22.24 \\
\hline Notomastus cf. lineatus & 13.33 & 0 & 6.18 & 1.23 & 7.06 & 29.3 \\
\hline Apseudopsis cf. acutifrons & 20 & 0 & 5.43 & 0.7 & 6.2 & 35.5 \\
\hline Leptocheirus mariae & 20 & 0 & 4.79 & 0.59 & 5.47 & 40.97 \\
\hline Thysiara flexuosa & 10 & 0 & 4.68 & 0.84 & 5.34 & 46.31 \\
\hline \multicolumn{7}{|l|}{ Intermediate / Close1 $(89.20 \%)$} \\
\hline Sternaspis scutata & 10 & 12.5 & 12.69 & 1.11 & 14.22 & 14.22 \\
\hline Oestergrenia digitata & 1.88 & 7.5 & 7.76 & 0.59 & 8.69 & 22.92 \\
\hline Scalibregma celticum & 0 & 8.75 & 5.77 & 0.37 & 6.47 & 29.39 \\
\hline Glycera unicornis & 1.25 & 6.25 & 5.44 & 0.79 & 6.09 & 35.48 \\
\hline Unidentified ophiuroid & 1.25 & 3.75 & 4.69 & 0.6 & 5.26 & 40.74 \\
\hline Nephtys kersivalensis & 3.75 & 0 & 4.49 & 0.46 & 5.03 & 45.77 \\
\hline \multicolumn{7}{|l|}{ Far / Close2 $(91.17 \%)$} \\
\hline Levinsenia sp.1 & 1.11 & 30 & 4.98 & 1.15 & 5.46 & 5.46 \\
\hline Sternaspis scutata & 24.44 & 6.67 & 4.59 & 0.83 & 5.03 & 10.49 \\
\hline \multicolumn{7}{|l|}{ Intermediate / Close2 (93.18\%) } \\
\hline Levinsenia sp.1 & 0 & 30 & 6.57 & 1.36 & 7.05 & 7.05 \\
\hline Lumbrineris latreilli & 0 & 13.33 & 5.51 & 0.81 & 5.91 & 12.96 \\
\hline Aponuphis ornata & 3.75 & 20 & 5.39 & 1.54 & 5.78 & 18.74 \\
\hline Heterospio sp. & 0 & 20 & 4.74 & 1.22 & 5.09 & 23.83 \\
\hline \multicolumn{7}{|l|}{ Close1 / Close2 (93.40\%) } \\
\hline Levinsenia sp.1 & 0 & 30 & 6.58 & 1.34 & 7.05 & 7.05 \\
\hline Aponuphis ornata & 0 & 20 & 5.73 & 1.65 & 6.14 & 13.18 \\
\hline Lumbrineris latreilli & 0 & 13.33 & 5.5 & 0.81 & 5.89 & 19.07 \\
\hline Heterospio sp. & 0 & 20 & 4.75 & 1.21 & 5.08 & 24.16 \\
\hline
\end{tabular}


Table 7.- Summary of the one-way ANOVA for the environmental variables and assemblage descriptors. Bold: significant differences; italics: relevant but nonsignificant differences. DoF: Degrees of freedom; SS: sum of squares; MS: mean squares; F: Fisher index; $p$ : probability.

\begin{tabular}{|c|c|c|c|c|c|}
\hline SOURCE & DoF & SS & MS & $\mathrm{F}$ & $P$ \\
\hline Distance $(\mathrm{km})$ & 3 & 14413.073 & 4804.358 & 2.247 & 0.160 \\
\hline Depth (m) & 3 & 1498.383 & 499.461 & 1.429 & 0.304 \\
\hline Escherichia coli & 3 & 0.800 & 0.267 & 0.364 & 0.781 \\
\hline Enterococci & 3 & 474.917 & 158.306 & 0.405 & 0.754 \\
\hline Silt & 3 & 96.271 & 32.090 & 10.355 & 0.004 \\
\hline Clay & 3 & 229.239 & 76.413 & 4.384 & 0.042 \\
\hline Very fine sands & 3 & 200.510 & 66.837 & 5.896 & 0.020 \\
\hline Fine sands & 3 & 0.363 & 0.121 & 0.612 & 0.626 \\
\hline Coarse sands & 3 & 0.231 & 0.077 & 1.005 & 0.439 \\
\hline Pore Water & 3 & 151.704 & 50.568 & 4.540 & 0.039 \\
\hline Organic matter & 3 & 151.704 & 50.568 & 4.540 & 0.039 \\
\hline Organic Carbon & 3 & 48.455 & 16.152 & 3.891 & 0.055 \\
\hline N (Kjeldahl) & 3 & 128980.000 & 42993.333 & 4.562 & 0.038 \\
\hline $\mathrm{P}$ & 3 & 4467.200 & 1489.067 & 1.179 & 0.377 \\
\hline $\mathrm{Al}$ & 3 & 81067610.667 & 27022536.889 & 1.753 & 0.234 \\
\hline $\mathrm{Ar}$ & 3 & 17.297 & 5.766 & 1.092 & 0.407 \\
\hline Cd & 3 & 0.026 & 0.009 & 867.056 & $<0.0001$ \\
\hline $\mathrm{Cr}$ & 3 & 272.053 & 90.684 & 4.405 & 0.042 \\
\hline $\mathrm{Cu}$ & 3 & 269.338 & 89.779 & 11.178 & 0.003 \\
\hline $\mathrm{Fe}$ & 3 & 2671127.717 & 890375.906 & 0.313 & 0.816 \\
\hline $\mathrm{Hg}$ & 3 & 0.100 & 0.033 & 21.436 & $<0.0001$ \\
\hline $\mathrm{Ni}$ & 3 & 42.649 & 14.216 & 1.482 & 0.291 \\
\hline $\mathrm{Pb}$ & 3 & 257.108 & 85.703 & 1.018 & 0.434 \\
\hline $\mathrm{Zn}$ & 3 & 1085.648 & 361.883 & 2.644 & 0.121 \\
\hline Hydrocarbons (C10-C40) & 3 & 2567.583 & 855.861 & 2.554 & 0.129 \\
\hline PAHs & 3 & 1374998.383 & 458332.794 & 6.016 & 0.019 \\
\hline PCBs & 3 & 1173.289 & 391.096 & 19.229 & 0.001 \\
\hline Chl-a & 3 & 0.886 & 0.295 & 1.399 & 0.312 \\
\hline $\mathrm{POC}$ & 3 & 11431.250 & 3810.417 & 2.217 & 0.164 \\
\hline TEMP & 3 & 0.526 & 0.175 & 2.716 & 0.115 \\
\hline Species Richness & 3 & 1949.450 & 649.817 & 21.352 & $<0.0001$ \\
\hline Density & 3 & 114083.264 & 38027.755 & 17.107 & 0.001 \\
\hline Biomass & 3 & 7.310 & 2.437 & 13.156 & 0.002 \\
\hline Diversity & 3 & 5.653 & 1.884 & 7.298 & 0.011 \\
\hline Evenness & 3 & 180.591 & 60.197 & 3.564 & 0.067 \\
\hline Trophic index & 3 & 477.984 & 159.328 & 3.172 & 0.085 \\
\hline AMBI & 3 & 0.054 & 0.018 & 0.224 & 0.877 \\
\hline$M-A M B I$ & 3 & 0.024 & 0.008 & 3.584 & 0.066 \\
\hline
\end{tabular}


Table 8. Results of the MaxEnt modelling. RM: Regularization multiplier; AUC: mean area under curve scores; Var +: variables positively influencing the suitability; Var -: variables negatively influencing the suitability.

\begin{tabular}{|c|c|c|c|c|}
\hline Species & RM & AUC & Var + & Var - \\
\hline Sternaspis scutata & 4 & $0.567 \pm 0.367$ & $\mathrm{P}$ & Chl-a, and very fine, fine, medium sands \\
\hline Aponuphis ornata & 4 & $0.989 \pm 0.018$ & Silt & Anthracene, very fine, fine, medium sands \\
\hline Drilonereis filum & 5 & $0.769 \pm 0.399$ & - & $\begin{array}{l}\text { Fine, medium sands, anthracene, PCB118, } \\
\text { PCB180, total PCBs }\end{array}$ \\
\hline Lumbrineris latreilli & 4 & $0.777 \pm 0.201$ & Silt & Very fine, fine, medium sands \\
\hline Goniada maculata & 4 & $0.852 \pm 0.203$ & Silt & Very fine, fine, medium sands \\
\hline Levinsenia sp.1 & 4 & $0.865 \pm 0.209$ & Silt & Very fine, fine, medium sands \\
\hline Glycera unicornis & 4 & $0.640 \pm 0.019$ & - & Very fine, fine, medium sands \\
\hline Mastobranchus trinchesii & 5 & $0.804 \pm 0.339$ & Silt & Very fine, fine, medium sands, anthracene \\
\hline Nephtys kersivalensis & 5 & $0.708 \pm 0.328$ & Silt & Very fine, fine, medium sands, anthracene \\
\hline Oestergrenia digitata & 4 & $0.750 \pm 0.250$ & - & Fine, medium sands \\
\hline Amphiura chiajei & 4 & $0.871 \pm 0.212$ & Silt & Very fine, fine, medium sands \\
\hline Nucula sulcata & 4 & $0.571 \pm 0.117$ & Silt & Very fine, fine, medium, coarse sands \\
\hline Thyasira flexuosa & 5 & $0.651 \pm 0.063$ & - & Fine, medium, coarse sands \\
\hline
\end{tabular}




\section{Syupplementary material}

Figure S1.- Jack-knife test of variable importance on the average model for Driloneris filum. Values shown are average over replicate runs.

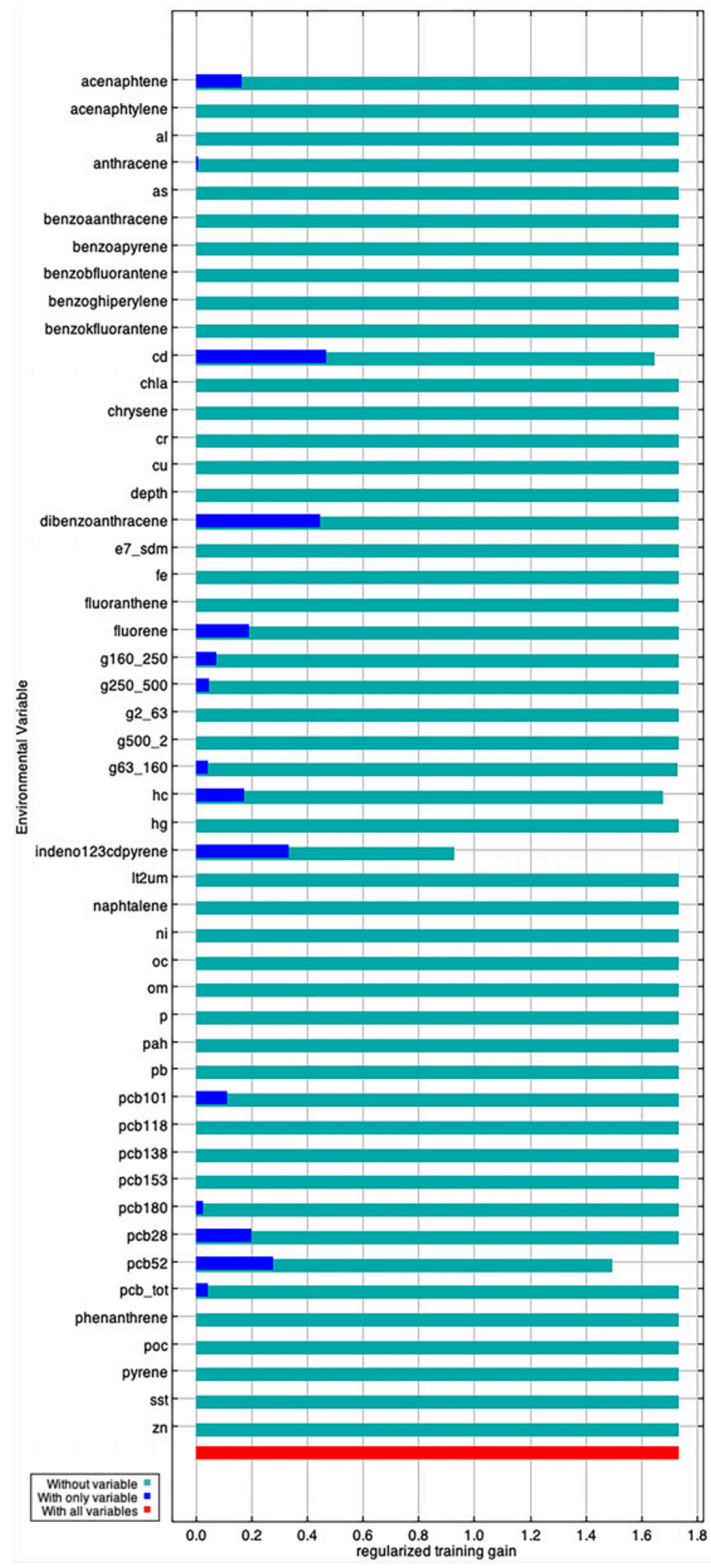


Figure S2.- Jack-knife test of variable importance on the average model for Glycera unicornis. Values shown are average over replicate runs.

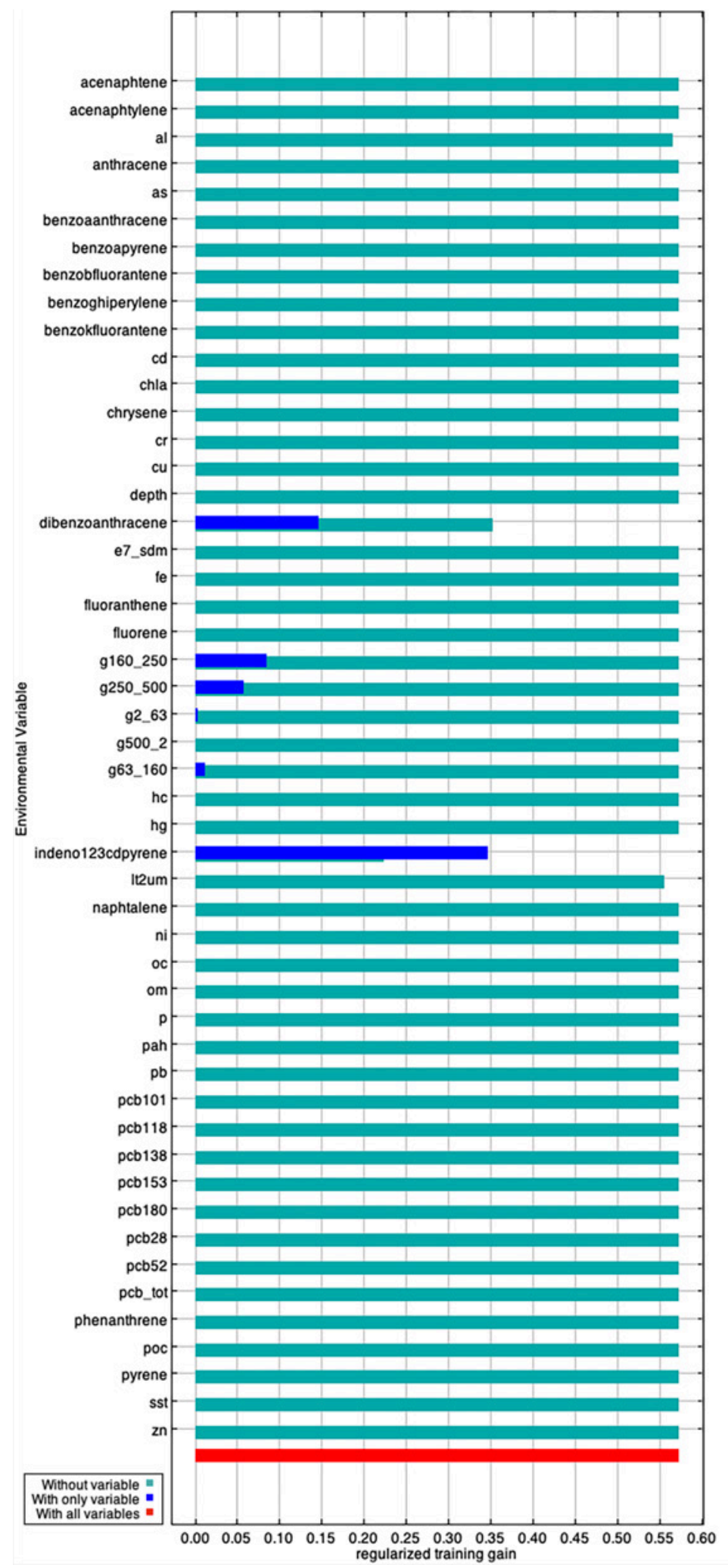


Figure S3.- Jack-knife test of variable importance on the average model for Nucula sulcata. Values shown are average over replicate runs.

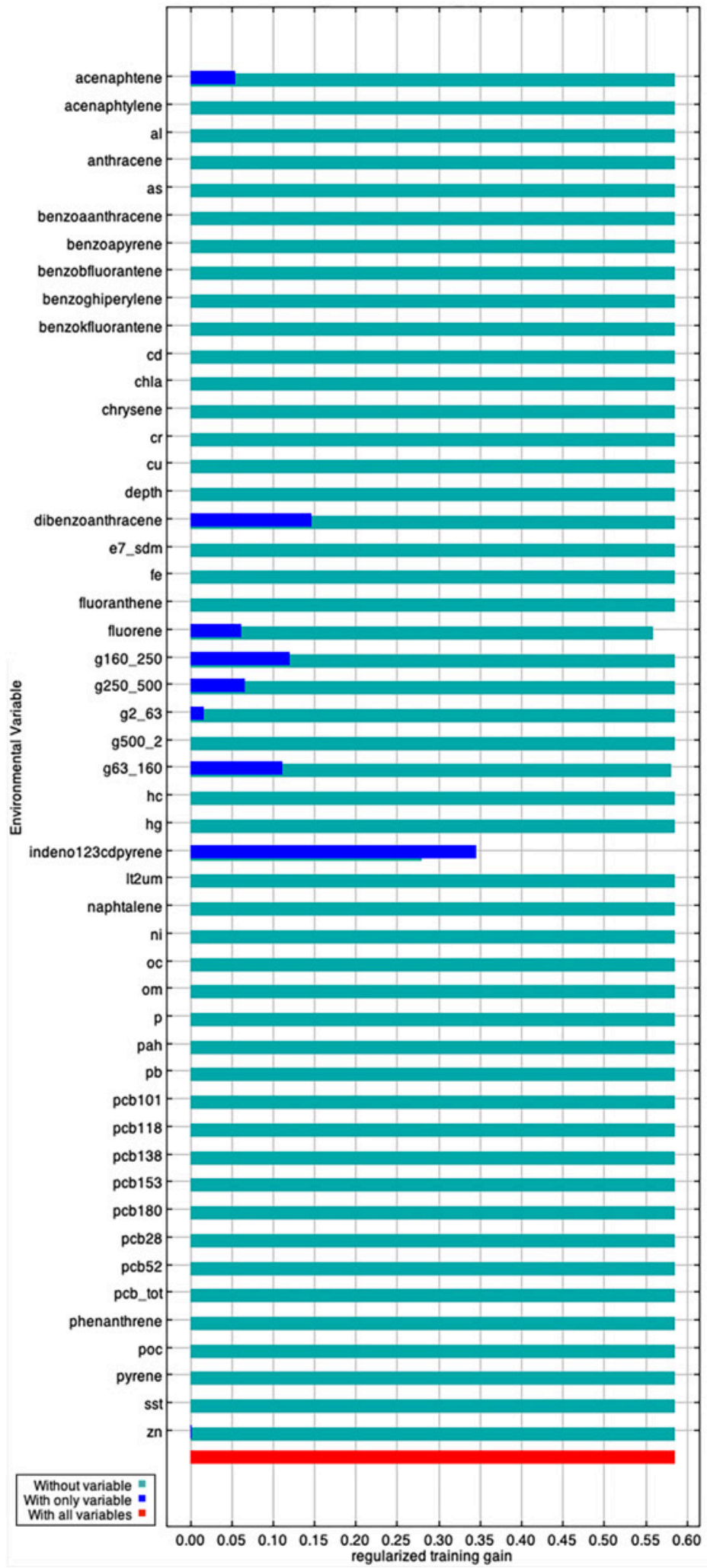


Figure S4.- Jack-knife test of variable importance on the average model for Thyasira flexuosa. Values shown are average over replicate runs.

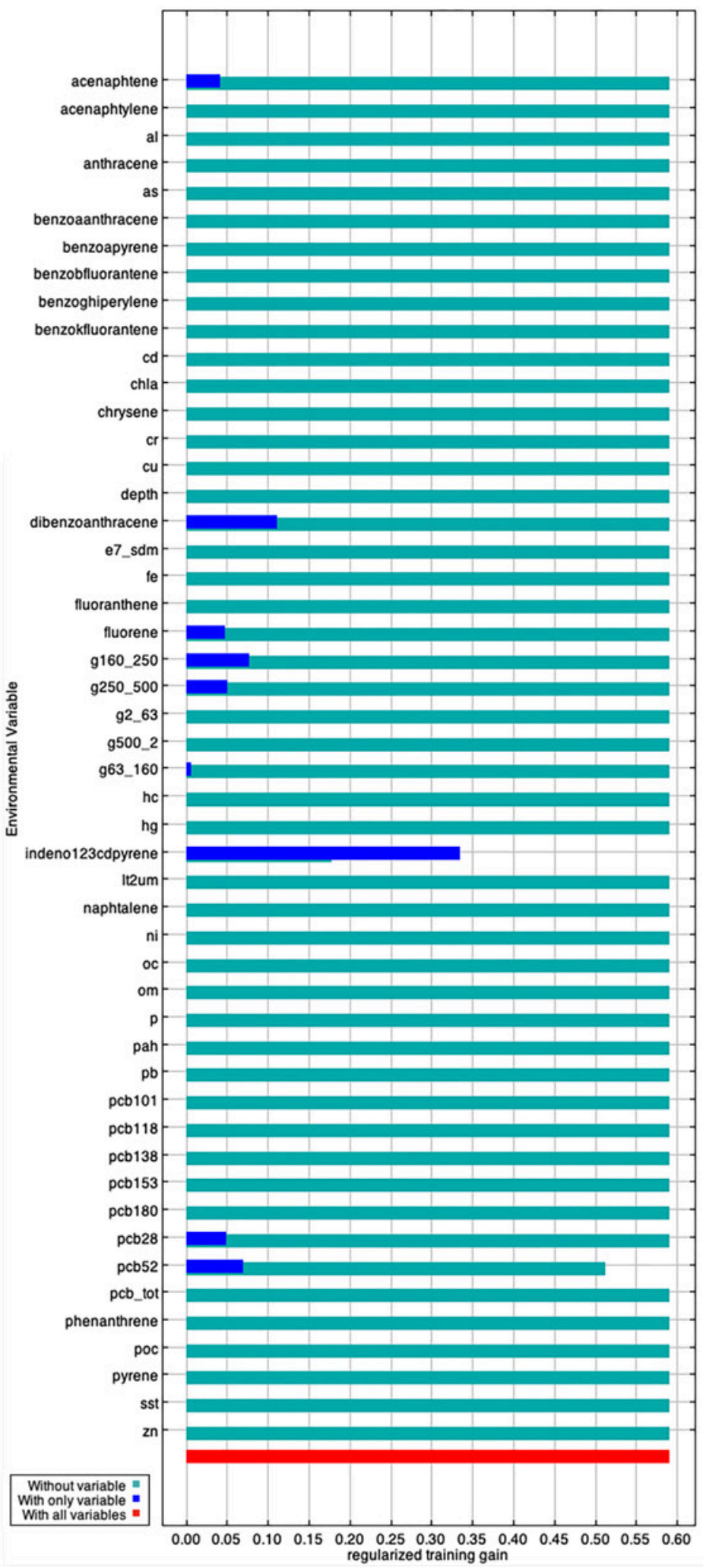


Table S1.- List of emerging pollutants below the detection level.

\begin{tabular}{lcccccc}
\hline Organochlorine pesticides & Units & S1 & S3 & S5 & S8 & S10 \\
\hline 2.4 DDT & $\mu \mathrm{g} / \mathrm{kg}$ & $<1$ & $<1$ & $<1$ & $<1$ & $<1$ \\
Aldrin & $\mu \mathrm{g} / \mathrm{kg}$ & $<1$ & $<1$ & $<1$ & $<1$ & $<1$ \\
Dieldrin & $\mu \mathrm{g} / \mathrm{kg}$ & $<1$ & $<1$ & $<1$ & $<1$ & $<1$ \\
Alpha endosulphan & $\mu \mathrm{g} / \mathrm{kg}$ & $<1$ & $<1$ & $<1$ & $<1$ & $<1$ \\
Beta endosulphan & $\mu \mathrm{g} / \mathrm{kg}$ & $<1$ & $<1$ & $<1$ & $<1$ & $<1$ \\
Sulphate endosulphan & $\mu \mathrm{g} / \mathrm{kg}$ & $<1$ & $<1$ & $<1$ & $<1$ & $<1$ \\
Total endosulphan & $\mu \mathrm{g} / \mathrm{kg}$ & $<1$ & $<1$ & $<1$ & $<1$ & $<1$ \\
Endrin & $\mu \mathrm{g} / \mathrm{kg}$ & $<1$ & $<1$ & $<1$ & $<1$ & $<1$ \\
HCB (hexachlorobenzene) & $\mu \mathrm{g} / \mathrm{kg}$ & $<1$ & $<1$ & $<1$ & $<1$ & $<1$ \\
Alpha HCH & $\mu \mathrm{g} / \mathrm{kg}$ & $<1$ & $<1$ & $<1$ & $<1$ & $<1$ \\
Beta HCH & $\mu \mathrm{g} / \mathrm{kg}$ & $<1$ & $<1$ & $<1$ & $<1$ & $<1$ \\
Delta HCH & $\mu \mathrm{g} / \mathrm{kg}$ & $<1$ & $<1$ & $<1$ & $<1$ & $<1$ \\
Isodrin & $\mu \mathrm{g} / \mathrm{kg}$ & $<1$ & $<1$ & $<1$ & $<1$ & $<1$ \\
Lindane (gamma HCH) & $\mu \mathrm{g} / \mathrm{kg}$ & $<1$ & $<1$ & $<1$ & $<1$ & $<1$ \\
\hline Organophosphorus pestides
\end{tabular}

Organophosphorus pesticides

\begin{tabular}{|c|c|c|c|c|c|c|}
\hline Fenitrothion & $\mu \mathrm{g} / \mathrm{kg}$ & $<1$ & $<1$ & $<1$ & $<1$ & $<1$ \\
\hline \multicolumn{7}{|l|}{ Anilines } \\
\hline Trifluralin & $\mu \mathrm{g} / \mathrm{kg}$ & $<1$ & $<1$ & $<1$ & $<1$ & $<1$ \\
\hline \multicolumn{7}{|l|}{ Dioxins } \\
\hline 1,2,3,4,6,7,8-Heptachlorodibenzofurane & $\mathrm{ng} / \mathrm{kg}$ & $<0.3$ & $<0.3$ & $<0.3$ & $<0.3$ & $<0.3$ \\
\hline 1,2,3,4,7,8,9-Heptachlorodibenzofurane & $\mathrm{ng} / \mathrm{kg}$ & $<0.1$ & $<0.1$ & $<0.1$ & $<0.1$ & $<0.1$ \\
\hline 1,2,3,4,7,8-Hexachlorodibenzodioxine & $\mathrm{ng} / \mathrm{kg}$ & $<0.1$ & $<0.1$ & $<0.1$ & $<0.1$ & $<0.1$ \\
\hline $1,2,3,4,7,8$-Hexachlorodibenzofurane & $\mathrm{ng} / \mathrm{kg}$ & $<0.1$ & $<0.1$ & $<0.1$ & $<0.1$ & $<0.1$ \\
\hline $1,2,3,6,7,8$-Hexachlorodibenzodioxine & $\mathrm{ng} / \mathrm{kg}$ & $<0.1$ & $<0.1$ & $<0.1$ & $<0.1$ & $<0.1$ \\
\hline 1,2,3,6,7,8-Hexachlorodibenzofurane & $\mathrm{ng} / \mathrm{kg}$ & $<0.1$ & $<0.1$ & $<0.1$ & $<0.1$ & $<0.1$ \\
\hline 1,2,3,7,8,9-Hexachlorodibenzodioxine & $\mathrm{ng} / \mathrm{kg}$ & $<0.1$ & $<0.1$ & $<0.1$ & $<0.1$ & $<0.1$ \\
\hline $1,2,3,7,8,9$-Hexachlorodibenzofurane & $\mathrm{ng} / \mathrm{kg}$ & $<0.1$ & $<0.1$ & $<0.1$ & $<0.1$ & $<0.1$ \\
\hline 1,2,3,7,8-Pentachlorodibenzodioxine & $\mathrm{ng} / \mathrm{kg}$ & $<0.1$ & $<0.1$ & $<0.1$ & $<0.1$ & $<0.1$ \\
\hline 1,2,3,7,8-Pentachlorodibenzofurane & $\mathrm{ng} / \mathrm{kg}$ & $<0.1$ & $<0.1$ & $<0.1$ & $<0.1$ & $<0.1$ \\
\hline 2,3,4,6,7,8-Hexachlorodibenzofurane & $\mathrm{ng} / \mathrm{kg}$ & $<0.1$ & $<0.1$ & $<0.1$ & $<0.1$ & $<0.1$ \\
\hline 2,3,4,7,8-Pentachlorodibenzofurane & $\mathrm{ng} / \mathrm{kg}$ & $<0.1$ & $<0.1$ & $<0.1$ & $<0.1$ & $<0.1$ \\
\hline 2,3,7,8-Tetrachlorodibenzodioxin & $\mathrm{ng} / \mathrm{kg}$ & $<0.1$ & $<0.1$ & $<0.1$ & $<0.1$ & $<0.1$ \\
\hline Octachlorodibenzofurane & $\mathrm{ng} / \mathrm{kg}$ & $<4$ & $<4$ & $<4$ & $<4$ & $<4$ \\
\hline Hexachlorodibenzodioxine & $\mathrm{ng} / \mathrm{kg}$ & $<0.1$ & $<0.1$ & $<0.1$ & $<0.1$ & $<0.1$ \\
\hline
\end{tabular}

PBDE: brominated diphenyl ethers

$\mathrm{ng} / \mathrm{kg}<200<200<200<200<200$


2,2 ', 4,4', 6- pentabromodiphenyl

2,4,4' tribromodiphenyl

$\mathrm{ng} / \mathrm{kg} \quad<100<100<100<100<100$

2,2', 4,4' tetrabromodiphenyl

2,2 ', 3,4,4'- pentabromodiphenylether

$\mathrm{ng} / \mathrm{kg} \quad<20<20 \quad<20 \quad<20 \quad<20$

2,2', 4,4', 5,6'-hexabromodiphenyl (BDE154)

$\mathrm{ng} / \mathrm{kg} \quad<1000<1000<1000<1000<1000$

2,2 ', 4,4', 5,6-hexabromodiphenyl (BDE153)

$\mathrm{ng} / \mathrm{kg} \quad<20 \quad<20 \quad<20 \quad<20 \quad<20$

$\mathrm{ng} / \mathrm{kg} \quad<20 \quad<20 \quad<20 \quad<20 \quad<20$

2,2 ', 3,4,4', 5 ', 6-heptabromodiphenyl (BDE183)

$\mathrm{ng} / \mathrm{kg} \quad<20 \quad<20 \quad<20 \quad<20 \quad<20$

DecaBDE (BDE209)

$\mathrm{ng} / \mathrm{kg} \quad<20<20 \quad<20 \quad<20<20$

Sum of penta BDE

$\mathrm{ng} / \mathrm{kg}<20000<20000<20000<20000<20000$

Nonabromodiphenyl (BDE206)

$\mathrm{ng} / \mathrm{kg}<200<200<200<200<200$

Nonabromodiphenyl (BDE207)

$\mathrm{ng} / \mathrm{kg} \quad<1000<1000<1000<1000<1000$

Octabromodiphenylether (BDE207)

$\mathrm{ng} / \mathrm{kg} \quad<1000<1000<1000<1000<1000$

PFCA: perfluorinated acids and derivatives

\begin{tabular}{lllllll}
\hline Pentachlorophenol & $\mu \mathrm{g} / \mathrm{kg}$ & $<10$ & $<10$ & $<10$ & $<10$ & $<10$ \\
Nonylphenols & $\mu \mathrm{g} / \mathrm{kg}$ & $<10$ & $<10$ & $<10$ & $<10$ & $<10$ \\
Octylphenols & $\mu \mathrm{g} / \mathrm{kg}$ & $<10$ & $<10$ & $<10$ & $<10$ & $<10$ \\
4-tert-octylphenol & $\mu \mathrm{g} / \mathrm{kg}$ & $<10$ & $<10$ & $<10$ & $<10$ & $<10$ \\
4-branched nonylphenols & $\mu \mathrm{g} / \mathrm{kg}$ & $<10$ & $<10$ & $<10$ & $<10$ & $<10$ \\
4-n-octylphenol & $\mu \mathrm{g} / \mathrm{kg}$ & $<10$ & $<10$ & $<10$ & $<10$ & $<10$ \\
4-n nonylphenol & $\mu \mathrm{g} / \mathrm{kg}$ & $<10$ & $<10$ & $<10$ & $<10$ & $<10$ \\
\hline Other compounds & & & & & & \\
\hline Hexabromocyclododecane & $\mathrm{mg} / \mathrm{kg}$ & $<0.01$ & $<0.01$ & $<0.01$ & $<0.01$ & $<0.01$ \\
Tetrabromobisphenol-A & $\mathrm{mg} / \mathrm{kg}$ & $<0.01$ & $<0.01$ & $<0.01$ & $<0.01$ & $<0.01$ \\
\hline
\end{tabular}

